\title{
Ongoing and planned activities to improve the management of patients with Type 1 diabetes across Africa; implications for the future
}

\section{Ongoing and planned activities to improve the management of patients with Type 1 diabetes across Africa; implications for the future}

Brian Godman 1,2,3,4, Debashis Basu ${ }^{5}$, Yogan Pillay ${ }^{6}$, Paulo H. R. F. Almeida ${ }^{7,8}$, Julius C. Mwita9, Godfrey Mutashambara Rwegerera ${ }^{10}$, Bene D Anand Paramadhas ${ }^{11}$, Celda Tiroyakgosi ${ }^{12}$, Okwen Patrick ${ }^{13,14}$, Loveline Lum Niba ${ }^{13,15}$, Israel Sefah ${ }^{16}$, Margaret Oluka ${ }^{17}$, Anastasia N Guantai ${ }^{17}$, Dan Kibuule $^{18}$, Francis Kalemeera ${ }^{18}$, Mwangana Mubita ${ }^{18}$, Joseph Fadare ${ }^{19,20}$, Olayinka O. Ogunleye ${ }^{21,} 22$, Enos M Rampamba ${ }^{2,23}$, Jeffrey Wing ${ }^{24}$, Debjani Mueller ${ }^{5,24}$, Abubakr Alfadl ${ }^{25,26}$, Adefolarin A Amu² Zinhle Matsebula ${ }^{28}$, Aubrey Kalungia ${ }^{29}$, Trust Zaranyika ${ }^{30}$, Nyasha Masuka ${ }^{31}$, Janney Wale ${ }^{32}$, Ruaraidh Hill ${ }^{33}$, Amanj Kurdi ${ }^{1,34}$, Angela Timoney ${ }^{1,35}$, Stephen Campbell ${ }^{36,37}$, Johanna C Meyer ${ }^{2}$

${ }^{1}$ Strathclyde Institute of Pharmacy and Biomedical Sciences, University of Strathclyde, Glasgow G4 ORE, United Kingdom. Email: amanj.baker@strath.ac.uk; brian.godman@strath.ac.uk

2Division of Public Health Pharmacy and Management, School of Pharmacy, Sefako Makgatho Health Sciences University, Pretoria, South Africa. Email: mrampamba@gmail.com;

hannelie.meyer@smu.ac.za

${ }^{3}$ Division of Clinical Pharmacology, Karolinska Institute, Karolinska University Hospital Huddinge, Stockholm, Sweden. Email: Brian.Godman@ki.se

${ }^{4}$ Health Economics Centre, University of Liverpool Management School, Liverpool, UK. Email:

Brian.Godman@liverpool.ac.uk

${ }^{5}$ Department of Public Health Medicine, Steve Biko Academic Hospital and the University of Pretoria, Steve Biko Road Prinshof 349-Jr, Pretoria, 0002 South Africa. Email: debashis.basu@up.ac.za ${ }^{6}$ National Department of Health, Pretoria, South Africa. Email: Yogan.Pillay@health.gov.za ${ }^{7}$ School of Pharmacy, Postgraduate Program in Medicines and Pharmaceutical Services, Federal University of Minas Gerais (UFMG), Belo Horizonte, Minas Gerais, Brazil. Email:

henriqueribeiro.farm@gmail.com

${ }^{8}$ Departamento de Gestão e Incorporação de Tecnologias e Inovação em Saúde, Secretaria de Ciência, Tecnologia, Inovação e Insumos Estratégicos em Saúde, Ministry of Health of Brazil, Esplanada dos Ministérios, Bloco G, Brasília, Distrito Federal, Brazil

${ }^{9}$ Department of Internal Medicine, Faculty of Medicine, University of Botswana, Gaborone, Botswana. Email: mwitajc@ub.ac.bw

${ }^{10}$ Faculty of Medicine, Department of Internal Medicine, University of Botswana and Department of Medicine, Princess Marina Hospital, Gaborone, Botswana. Email: grwege@yahoo.com

${ }^{11}$ Department of Pharmacy, Central Medical Stores, Gaborone,, Botswana. Email:

anandbene@yahoo.com

${ }^{12}$ Botswana Essential Drugs Action Program, Ministry of Health and Wellness, Nelson Mandela Drive, Gaborone, Botswana. Email: ctiroyakgosi@gov.bw

${ }^{13}$ Effective Basic Services (eBASE) Africa, Ndamukong Street, Bamenda, Cameroon, Africa. Email: okwen@ebaseafrica.org; lovelinelum@ebaseafrica.org

${ }^{14}$ Adelaide University, Adelaide, Australia. Email: patrick.okwen@adelaide.edu.au

${ }^{15}$ Department of Public Health, University of Bamenda, P.O. Box 39, Bambili, Cameroon

${ }^{16}$ Department of Pharmacy, Keta Municipal Hospital, Ghana Health Service, Keta, Ghana. Email: sefrael@yahoo.com

${ }^{17}$ Department of Pharmacology and Pharmacognosy, School of Pharmacy, University of Nairobi, P.O Box 19676-00202, Nairobi, Kenya. Email: olukamarga@yahoo.com; dean-pharmacy@uonbi.ac.ke ${ }^{18}$ Department of Pharmacy Practice and Policy, Faculty of Health Sciences, University of Namibia, Windhoek, Namibia. Email: dkibuule@unam.na; fkalemeera@unam.na; mmubita@unam.na ${ }^{19}$ Department of Pharmacology and Therapeutics, Ekiti State University, Ado-Ekiti, Nigeria. Email: joseph.fadare@eksu.edu.ng

${ }^{20}$ Department of Medicine, Ekiti State University Teaching Hospital, Ado-Ekiti, Nigeria

${ }^{21}$ Department of Pharmacology, Therapeutics and Toxicology, Lagos State University College of Medicine, Ikeja, Lagos, Nigeria. Email: yinkabode@yahoo.com

${ }^{22}$ Department of Medicine, Lagos State University Teaching Hospital, Ikeja, Lagos, Nigeria

${ }^{23}$ Department of Health, Tshilidzini Hospital, Shayandima, Limpopo Province, South Africa. Email: mrampamba@gmail.com

${ }^{24}$ Charlotte Maxeke Medical Research Cluster, Johannesburg, South Africa; Email:

dbmueller7@yahoo.de; Jeffrey.wing@wits.ac.za 
${ }^{25}$ National Medicines Board, Federal Ministry of Health, Khartoum, Sudan; Email: abubakr13@yahoo.com

26Unaizah College of Pharmacy, Qassim University, Buraidah, Saudi Arabia

${ }^{27}$ Eswatini Medical Christian University, P.O Box A624, Swazi Plaza, Mbabane, Kingdom of Eswatini. Email: amuadefolarin@scu.ac.sz

${ }^{28}$ Raleigh Fitkin Memorial Hospital, Manzini, Kingdom of Eswatini. Email: zmkholo@gmail.com

29Department of Pharmacy, University of Zambia, Lusaka, Zambia. Email: ckalungia@unza.zm

${ }^{30}$ Department Of Medicine, University of Zimbabwe College of Health Sciences, Harare, Zimbabwe.

Email: zaranyikatrust@gmail.com

${ }^{31}$ Independent Health Systems Consultant, Harare, Zimbabwe. Email: docnyasha@gmail.com

${ }^{32}$ Independent consumer advocate, 11a Lydia Street, Brunswick, Victoria 3056, Australia. Email: socrates111@bigpond.com

${ }^{33}$ Liverpool Reviews and Implementation Group, Whelan Building, Liverpool University, Liverpool, UK L693GB. Email: ruaraidh.hill@liverpool.ac.uk

${ }^{34}$ Department of Pharmacology, College of Pharmacy, Hawler Medical University, Erbil, Iraq

${ }^{35} \mathrm{NHS}$ Lothian Director of Pharmacy, NHS Lothian, Edinburgh, UK. Email:

angela.timoney@nhslothian.scot.nhs.uk

${ }^{36}$ Centre for Primary Care, Division of Population Health, Health Services Research and Primary

Care, University of Manchester, Manchester, M13 9PL, UK. Email:

stephen.campbell@manchester.ac.uk

${ }^{37} \mathrm{NIHR}$ Greater Manchester Patient Safety Translational Research Centre, School of Health

Sciences, University of Manchester, Manchester, UK

*Author for correspondence: Strathclyde Institute of Pharmacy and Biomedical Sciences, University of Strathclyde, Glasgow G4 ORE, United Kingdom. Email: brian.godman@strath.ac.uk. Telephone: 0141548 3825. Fax: 01415522562 and Division of Clinical Pharmacology, Karolinska Institute, Karolinska University Hospital Huddinge, SE-141 86, Stockholm, Sweden. Email:

Brian.Godman@ki.se. Telephone + 468 58581068. Fax + 46859581070

\section{Abstract}

Background: Currently about 19 million people in Africa are known to be living diabetes, mainly Type 2 diabetes (T2DM) (95\%), estimated to grow to 47 million people by 2045 . However, there are concerns with early diagnosis of patients with Type 1 diabetes (T1DM) as often patients present late with complications. There are also challenges with access and affordability of insulin, monitoring equipment and test strips with typically high patient co-payments, which can be catastrophic for families. These challenges negatively impact on the quality of care of patients with T1DM increasing morbidity and mortality. There are also issues of patient education and psychosocial support adversely affecting patients' quality of life. These challenges need to be debated and potential future activities discussed to improve the future care of patients with T1DM across Africa. Methodology: Documentation of the current situation across Africa for patients with T1DM including the epidemiology, economics, and available treatments within public healthcare systems as well as ongoing activities to improve their future care. Subsequently, provide guidance to all key stakeholder groups going forward utilising input from senior level government, academic and other professionals from across Africa. Results: Whilst prevalence rates for T1DM are considerably lower than T2DM, there are concerns with late diagnosis as well as the routine provision of insulin and monitoring equipment across Africa. High patient co-payments exacerbate the situation. However, there are ongoing developments to address the multiple challenges including the instigation of universal health care and partnerships with non-governmental organisations, patient organisations and pharmaceutical companies. Their impact though remains to be seen. A range of activities have been documented for all key stakeholder groups to improve future care. Conclusion: There are concerns with the management of patients with T1DM across Africa. A number of activities have been suggested to address this and will be monitored.

\section{Introduction}

There is an increasing focus on the management of patients with non-communicable diseases (NCDs) including diabetes in Africa driven by growing prevalence rates as well as increasing costs to healthcare systems (1-3). Currently there are approximately 19 million people in Africa known to be diagnosed with diabetes, with an estimated 47 million likely to have diabetes by $2045(4,5)$, with 
almost a third of patients needing insulin for their diabetes (6). The vast majority of patients with diabetes in Africa have type 2 diabetes (T2DM), with higher prevalence rates of patients with T2DM versus type 1 diabetes (T1DM) seen in Africa compared with other parts of the world $(1,7-11)$. The latest estimates (2019) from the IDF suggest there are 25,800 children and adolescents $(0-19$ years) with T1DM in Africa, with 10,300 newly diagnosed cases each year (12). However, still a significant number of patients remain undiagnosed (12-14). There are also ongoing debates regarding the role of malnutrition in the development of T1DM among African children, as well as malnutritionrelated diabetes, enhancing the poor prognosis for T1DM patients in Africa especially those from resource-poor settings $(10,15)$.

Recent incidence and prevalence rates for patients with T1DM in Africa are documented in Table 1. However, prevalence rates are likely to be higher if the age of diagnosis is extended up to 26 years as opposed to 0 to 14 years $(1,15-17)$, with the age at diagnosis typically higher among the Black African population compared with the white population (18).

$\underline{\text { Table } 1 \text { - Epidemiology of Type } 1 \text { diabetes across Africa }}$

\section{Country}

General $(19,20)$

Botswana

Cameroon

Ethiopia

Gabon

Ghana

\section{Epidemiology}

- Incidence rates of 4.3 per 1000000 among African children aged between 0 to 14 years and 10.3 per 1000000 in those aged between 0 and 19 years

- Prevalence rates of 10.3 per 1000000 among African children aged between 0 to 14 years and 25.8 per 1000000 in those aged between 0 and 19 years

- These incidence and prevalence rates are appreciably lower than those seen in other regions of the world with incidence rates as high as 25.1 per 1000000 among children in Europe aged between 0 to 14 years and up to 31.1 per 1000000 in those aged between 0 and 19 years

- There is an increase in pregnant adolescent girls presenting with T1DM in SSA

- The IDF currently estimates that the national prevalence rates for diabetes among adults is $5.5 \%$ (12)

- The number of children and adolescents with T1DM in Botswana was recently (2019) estimated at 99 (21)

- The number of children and adolescents with T1DM in Cameroon was recently (2019) estimated at 743 (21)

- The incidence rate of diabetes among children in Ethiopia in 2013 aged between 0 and 14 years was 0.3 per 100,000 in $2013(22,23)$

- In their study, Balcha et al. (2018) found an appreciably higher rate of T1DM in urban areas (incidence rate of 11.9/ 100,000 for men and 6.1/ 100,000 for women) vs. rural areas (2.2/ 100,000 for men and 1.0/ 100,000 for women) (15)

- Currently in Ethiopia, it is estimated (2019) that 2127 children and adolescents have T1DM (21)

- Reported incidence rates of 3.4/ 100,000 inhabitants/ year in 2015 and 2.9 in 2017 (8)

- It is estimated that 89 children (2019) in Gabon currently have T1DM (21)

- The overall prevalence of diabetes in adults in Ghana was $3.3 \%$ in 2014; principally T2DM (24), with higher rates seen in urban towns $(24,25)$ 
Kenya

Morocco

Namibia

Nigeria

Rwanda

Somalia

South Africa

Sudan

Tanzania
- $\quad$ This has risen to $3.6 \%$ in $2017(518,400$ cases of diabetes in Ghana principally T2DM) (26)

- Currently in Ghana, it is estimated (2019) 1209 children and adolescents have T1DM (21)

- Currently in Kenya, it is estimated (2019) 1694 children and adolescents have T1DM (21)

- The overall prevalence of diabetes in adults in Morocco is $7.3 \%$, much of which will be patients with T2DM as opposed to T1DM (27-29)

- Adekanmbi et al. (2019) recently estimated the prevalence of diabetes in Namibia at $5.1 \%$ including patients with T1DM and T2DM (30)

- Currently it is estimated (2019) in Namibia that 127 children and adolescents have T1DM (21)

- Hospital based studies published in 2010 and 2013 showed prevalence rates of T1DM up to $3.1 / 1000$ among children aged 15 years or below $(31,32)$

- However, there is appreciable variation depending on the locality ranging from $0.1 / 1000$ in the South-East of Nigeria , $0.33 / 1000$ in Sokoto (extreme North-West of Nigeria), 2.3/1000 in Kano (North-West), and 10.1/1000 in Jos, North-Central (31, 33-35).

- The IDF currently estimates (2019) that there are 2954 children and adolescents in Nigeria with T1DM (21)

- The overall prevalence of diabetes in Rwanda is approximately $3 \%$ of the population, mainly T2DM (36)

- Currently (2019) there appear to be over 630 children and adolescents in Rwanda with T1DM (21)

- $\quad$ The IDF currently estimates (2019) that there are 57 children and adolescents in Somalia with T1DM (21)

- In South Africa in 2015, approximately 2.3 million people had diabetes principally T2DM (37), with estimates of 1599 children and adolescents with T1DM in 2019 (21)

- However there is a high rate of misdiagnosis in both sectors in South Africa as well as high rates of DKA (14)

- Diabetes Type 1A class found to be more prevalent among young black South Africans than their white/ Indian peers (38)

There is increase

- Incidence estimates were 10.3/100,000 in 1995 (39)

- Recently, the IDF currently estimated (2019) there are 208 children and adolescents in South Sudan with T1DM (21)

- Incidence rate among children in Tanzania aged between 0 and 14 years in 2013 was 0.9 per 100,000 in $2013(22,23)$

- More recently, Jasem et al. (2019) calculated an annual incidence of between 1.8 to 1.9 per 100,000 children aged under 15 years, with a peak incidence at 10 to 14 years (22)

- The IDF currently estimates (2019) there are 1984 children and adolescents in the Republic of Tanzania with T1DM (21) 
Zambia

Zimbabwe
- According to the $\mathrm{WHO}$, the overall prevalence of diabetes in Zambia is $4.2 \%$ with no breakdown between T1DM and T2DM (40)

- The number of children and adolescents with T1DM in Zambia is currently estimated at 557 (21)

- Among a total of 29,514 study participants, the overall pooled prevalence of diabetes in Zimbabwe including patients with T1DM before 1980 was $0.44 \%(95 \% \mathrm{Cl} 0.0-1.9 \%)$, and after 1980 the pooled prevalence was $5.7 \%(95 \% \mathrm{Cl} 3.3-8.6 \%)(41)$

- The IDF currently estimates (2019) there are 464 children and adolescents in Zimbabwe with T1DM (21)

NB: DKA= diabetic ketoacidosis; IDF: International Diabetes Federation; SSA: sub-Saharan Africa; T1DM: Type 1 Diabetes mellitus; T2DM: Type 2 Diabetes mellitus; WHO: World Health Organization

Typically in Africa, children with diabetes are insulin-dependent (90\%) and most likely autoimmune (42-44), with auto-immune beta-cell destruction having an important role in the pathogenesis of T1DM among African patients (45). There are a number of HLA class II alleles associated with T1DM among the black population in Southern Africa, which is important for future care delivery.

In 2019, it was estimated that there were 366,200 deaths attributable to diabetes across Africa (5). Concerns with the availability and costs of insulin as well as insulin resistance are key contributing factors to current mortality rates from diabetes in Africa (6).

The total costs of treating patients aged between 20 to 79 years with diabetes across Africa are currently estimated at US\$13billion (5), with out-of-pocket expenditure likely to exceed $50 \%$ of overall health expenditure in a number of African countries (1).These costs are exacerbated by the fact that patients with diabetes in hospitals have the longest stay due to diverse complications including stroke and amputations $(46,47)$. The total costs for treating patients with diabetes in SSA including direct medical costs are likely to increase to US $\$ 59$.32billion by 2030 (1), most of which will be for treating patients with T2DM. In 2015, Quaye et al estimated the mean annual financial cost of managing one diabetic case at hospital clinics in Ghana was US $\$ 372.65$, with medicines accounting for $71 \%$ of the total financial cost (48). In 2015, Pei estimated the total cost of diabetes for 40 households in Ghana, including patients with both T1DM and T2DM, was approximately $15,000 \mathrm{Cedi} /$ month of which $66.5 \%$ was direct costs (24). In view of the expenditures involved, $52.9 \%$ of the households surveyed in Ghana have experienced catastrophic health expenditure when family members are diagnosed with diabetes (24) (see Table 2 for further details). Suleiman et al. (2014) estimated the annual direct costs of treating patients with T1DM in Nigeria was NGN18 billion (US\$112.54million), with costs of NGN100,032.89 (US\$625.21) per patient (49).

There are concerns that governments and health systems across Africa are struggling to cope with the demand and cost of services to treat patients with diabetes and its complications unnecessarily increasing morbidity and mortality $(1,50)$. This includes concerns that children in Africa are at high risk of being diagnosed with T1DM late due to a lack of knowledge among parents, caregivers and school teachers (14). This is beginning to change with several initiatives now in place across Africa to improve the management of patients with diabetes. These include patient led strategies to strengthen healthcare systems, strategies to improve guideline adherence where there are concerns with suboptimal management, assist patients with appropriate lifestyle changes including diet and exercise, provide free medicines and diagnostic equipment as well as instigate quality targets $(7,20,51-70)$.

Despite its impact on the health of patients including early mortality, there are still concerns that patients with T1DM are not receiving evidence based care in Africa at the expense of initiatives to reduce morbidity and mortality associated with $\operatorname{T2DM}(7,20)$. Common causes of death in African children with diabetes include diabetic ketoacidosis (DKA), severe hypoglycaemia, infection and eventually microvascular complications $(13,43,71)$. Overall, DKA is the most common cause of death in children and adolescents with T1DM, accounting for approximately half of all deaths in patients younger than 24 years with diabetes $(10,72,73)$. Typically at diagnosis of T1DM in Africa, up to $80 \%$ or more of children and adolescents newly diagnosed with T1DM have DKA $(13,14,33,43,71,74$, 75). Independent risk factors associated with DKA in children include their age, parents' knowledge of the signs and symptoms of DKA, health care professional (HCP) education, erratic supply and poor adherence rates to prescribed medicines as well as infections before DKA $(71,76-78)$. High mortality 
rates due to DKA in developing countries including African countries are due to higher rates of infection, less developed medical service as well as delays in seeking care with over reliance on traditional medicines and healers $(13,32,71,72,79)$. Severe hypoglycaemia is also common among children in SSA, and is associated with high mortality $(43,80,81)$ as well as a substantial impact on both productivity and healthcare utilisation (82).

There are also concerns that lack of correction dosing for hyperglycaemia, lack of carbohydrate counting, and lack of access to rapid-acting insulin among children with T1DM results in poor glycaemic control, which negatively impacts on the quality of life of patients (83). Having said this, good management of nocturnal and daytime non-severe hypoglycaemic events that minimize hypoglycaemia while maintaining good glycaemic control may positively impact upon the psychological wellbeing of people with diabetes, reducing healthcare costs and improving productivity (84).

There are also concerns with the extent of complications among patients with T1DM across Africa including retinopathy, nephropathy, neuropathy and hypertension as well as infections including malaria and tuberculosis $(1,10,13,43,85-87)$. Improved diet as well as family support offering psychosocial support and assisting with correct and constant administration of medicines, including insulin, can help reduce the complications of T1DM (80). Psychosocial support is important with T1DM adversely affecting the quality of life of patients resulting in the need for all key stakeholder groups to work together to improve the care and lives of patients with T1DM (88-91). This includes the need to develop coping strategies and address issues of stigma (88), which are especially crucial if coping strategies involve avoiding injections (88). There is also a need to address concerns with the availability of dialysis services across Africa $(92,93)$.

While mortality and morbidity rates have improved among African countries in recent years in patients with T1DM, the gains seen in Africa are far less than those seen in developed countries (20). Published studies have suggested that up to $50 \%$ of patients with T1DM in Africa die in the first five years after diagnosis (8), and, the life expectancy of a child with T1DM can be as low as one year (94). There are a number of elements of care that adversely increase morbidity and mortality (20). These include failure to seek help, unavailability of regular screening programmes for patients suspected of having T1DM, inability to make a formal diagnosis, inadequate and inappropriate care exacerbated by the lack of equipment, facilities and professionals, e.g. Ghana currently has less than fifteen endocrinologists, poor knowledge among patients and parents, frequent episodes of hypoglycaemia exacerbated by a lack of insulin and the cost of insulin as well as monitoring sticks and syringes, poor storage of insulin, poor adherence to treatments and poor eating habits as well as cultural aspects of care $(1,6,20,24,43,44,62,63,80,95-104)$. The WHO in 2015 found that in SSA only $51 \%$ of the countries had metformin routinely available and only $40 \%$ had insulin readily available, well below the $80 \%$ target $(1,105)$. In addition, many African countries currently have inadequate facilities to manage both the microvascular and macrovascular complications of diabetes $(1,106)$. Consequently, a key area to address to improve the management of patients with T1DM across Africa along with healthcare strengthening is access to, and regular availability, of insulins as well as increased availability of blood glucose monitoring devices $(1,10,13,65,97)$. Poor availability and use of insulin are not helped by high costs and co-payments. We are beginning to see access programmes and other approaches among African countries to address concerns with insulin availability as well as a lack of education and facilities $(13,61,107-110)$. We are also seeing groups such as the International Diabetes Federation (IDF) improve access to HbA1c testing among African countries including Cameroon and Guinea $(64,65)$. Other key areas to address to improve patient care include patient empowerment on the knowledge of their disease and treatment to reduce nonadherence to insulins and rates of hypoglycaemia $(70,111,112)$. We do know that the control of diabetes in patients with T1DM does improve once they had been through any denial phase and accepted the condition and its implications on lifestyle requirements (63).

Table 2 provides more details regarding the economics and availability of insulin and glucose monitoring among African countries highlighting current challenges. Typically in Africa, the direct costs of treating diabetes approaches US $\$ 300 /$ patient corresponding to the annual income of many families (80).

The WHO lists soluble insulins and intermediate insulins in the 2019 Essential Medicines List (113), and these should be readily available to help patients with T1DM. However, there are concerns with 
the quality of low-cost generic insulins as these are more complex to produce than oral generic tablets $(43,97)$.

Table 2 - Economics of diabetes across Africa especially T1DM, insulin availability and glucose strips

\begin{tabular}{|c|c|}
\hline Country & Summary details \\
\hline Sub-Saharan Africa & $\begin{array}{l}\text { - Ogle et al. (2016) ascertained that the median cost of blood } \\
\text { glucose strips among seven African nations was US } \$ 0.50 \text {, } \\
\text { and the minimal reasonable yearly costs to families with a } \\
\text { child or adolescent with diabetes ranged from } 74 \% \text { to } 377 \% \\
\text { of per-capita gross income }(1,114) \\
\text { - The regular availability of monitors and test strips is rare for } \\
\text { most patients in African countries with the cost of monitoring } \\
\text { beyond the financial means of most families, and many } \\
\text { clinics currently cannot routinely measure glucose levels (43, } \\
114,115) \\
\text { - Only a limited number of governments among those } \\
\text { documented by Ogle et al. (2016) fully provided insulin (114) } \\
\text { The mean availability of insulins in the public sector ranged } \\
\text { from } 55 \% \text { to } 80 \% \text { among } 13 \text { LMICs including four African } \\
\text { countries (98). Median government procurement prices for human } \\
\text { insulins was US } \$ 5 \text { among the } 13 \text { countries (98) } \\
\text { Wide variations have been seen in the prices of a } 10-m l, 100- \\
\text { IU/ml vial equivalent of insulin ranging from US } \$ 1.0 \text { to US } \$ \\
11.5 \text { (median US } \$ 4.7) \text { among countries in the WHO } \\
\text { Regional Office for Africa (100) }\end{array}$ \\
\hline East Africa & $\begin{array}{l}\text { Many patients on cost and other grounds still reuse syringes, } \\
\text { which is discouraged as this can increase lipohypertropy }(116)\end{array}$ \\
\hline Burkina Faso & $\begin{array}{l}\text { Estimated published minimal annual direct costs of treating } \\
\text { T1DM patients and supplies is US\$1185 (114), equating to } 177 \% \\
\text { per capita income }\end{array}$ \\
\hline Cameroon & $\begin{array}{l}\text { Under the Changing Diabetes in Children (CdiC) programme, all } \\
\text { children and adolescents in Cameroon attending relevant centres } \\
\text { are provided with free insulin as well as glucose monitors and } \\
\text { strips to address current concerns with their access and } \\
\text { availability (63) }\end{array}$ \\
\hline Democratic Republic of Congo & $\begin{array}{l}<25 \% \text { of T1DM patients in the Republic had regular access to } \\
\text { insulin }<25 \% \text { of the time }(10)\end{array}$ \\
\hline Egypt & $\begin{array}{l}\text { - In their study, Zhang et al. (2010) documented Egypt's } \\
\text { healthcare expenditure for patients with diabetes including } \\
\text { both T1DM and T2DM reached US\$116 per person - 16\% of } \\
\text { total healthcare expenditure }(117,118) \\
\text { - Expenditures are currently likely to be considerably more } \\
\text { than this, with greater expenditure per person among } \\
\text { patients with T1DM versus T2DM }\end{array}$ \\
\hline Gabon & $\begin{array}{l}\text { Damiens et al. in their study (2019) found that in } 76 \% \text { of } \\
\text { patients with T1DM the cost of the medicines was an } \\
\text { obstacle to the adherence to the medicines prescribed (8), } \\
\text { with } 69 \% \text { saying they do not have a supply of blood sugar } \\
\text { test strips to adapt insulin doses } \\
\text { In view of the financial effects of the disease, if patients are } \\
\text { alive after } 4 \text { years post diagnosis they typically have poor } \\
\text { metabolic balances and recurrent DKA resulting in premature } \\
\text { death (8) }\end{array}$ \\
\hline Ghana & $\begin{array}{l}\text { - The total cost of diabetes for } 40 \text { households in Ghana } \\
\text { including patients with both T1DM and T2DM was } \\
\text { approximately } 15,000 \text { Cedi/month in } 2015 \text { of which } 66.5 \% \\
\text { was direct costs (24) }\end{array}$ \\
\hline
\end{tabular}




\begin{tabular}{|c|c|}
\hline & $\begin{array}{l}\text { - Overall, } 52.9 \% \text { of the households surveyed in Ghana } \\
\text { experienced catastrophic health expenditure (24) }\end{array}$ \\
\hline Kenya & $\begin{array}{l}\text { - Ngwiri et al. in their study (2015) found that } 69 \% \text { of children } \\
\text { there were concerns with the unavailability of mixed } \\
\text { formulation insulins ( } 80 \text { ) } \\
\text { - In their study, Pastakia et al. (2018) found that } 85 \% \text { of } \\
\text { patients with diabetes including both T1DM and T2DM being } \\
\text { treated at Webuye District Hospital (rural diabetes clinic) } \\
\text { received regular HbA1c testing (119). This is welcomed with } \\
\text { the average cost of HbA1c measurement at US10 - } 25 \text { with } \\
50 \% \text { of residents typically living on less than } 1 \text { US } \$ \text { / day ( } 43 \text {, } \\
120,121 \text { ) } \\
\text { The management of patients with diabetes in Kenya } \\
\text { including T1DM patients is a key Government objective to } \\
\text { reduce morbidity and mortality rates (69) } \\
\text { In their recent study, Shannon et al. (2019) found that despite } \\
\text { a ceiling price ceiling of US } \$ 5 \text { per vial of insulin, many } \\
\text { patients could not afford the additive expense of care } \\
\text { including monitoring, other medicines and travel to the } \\
\text { clinics. Encouragingly though, there was a greater number of } \\
\text { stock-outs among facilities not taking part in the access } \\
\text { scheme (61) }\end{array}$ \\
\hline Mozambique & $\begin{array}{l}\text { The government currently buys insulin at approximately } \\
\text { US } \$ 4.30 / \text { vial. Since the average person requires } 13 \text { vials a } \\
\text { year, the government must prioritise whether it provides } \\
\text { insulin for one person or essential medicines for nearly } 40 \\
\text { others (62) } \\
\text { In addition in Mozambique, previously only a limited number } \\
\text { of facilities have the necessary equipment to undertake blood } \\
\text { glucose analysis (62); however, this is now being addressed } \\
\text { with the help of the IDF }\end{array}$ \\
\hline Namibia & $\begin{array}{l}\text { - There is universal access to cost-free diabetic care in } \\
\text { Namibia's public sector, which can be accessed from primary } \\
\text { health care to tertiary institutions }(122) \\
\text { - A wide range of insulins including soluble and long acting } \\
\text { insulins are available to the public via PHCs financed by the } \\
\text { government of the Republic of Namibia } \\
\text { - A wide range of insulin preparations can also be accessed in } \\
\text { the private sector as well as through a cost sharing system, } \\
\text { Average co-payments range from US } \$ 3.4 \text { to US } \$ 5.1 \text { per vial. } \\
\text { Without medical aid insurance, the cost of insulin } \\
\text { preparations would range from US } \$ 11.3 \text { to US } \$ 17.1 \text { per vial } \\
\text { The challenges of managing patients with T1DM include: } \\
\text { long distances between homes and health care facilities for } \\
\text { people in the rural areas where the cost of transport and lost } \\
\text { wages needs to be factored in as well as a lack of } \\
\text { appropriate storage systems in rural settings }\end{array}$ \\
\hline Nigeria & $\begin{array}{l}\text { - Medication costs accounted for } 72.3 \% \text { of the total direct cost } \\
\text { of patients with diabetes followed by the cost of laboratory } \\
\text { investigations }(17.6 \%) \text {, with costs typically out-of-pocket } \\
\text { (123). Other studies have suggested that the costs of } \\
\text { medicines can account for up to } 90 \% \text { of total costs }(124) \\
\text { Ogbera et al. (2012) estimated the monthly mean costs of } \\
\text { insulin was } 5212.8 \text { Nigerian Naira (US } \$ 33.1 \text { ) equating to } \\
29 \% \text { of the minimum wage on insulin alone for patients with } \\
\text { T1DM (125) } \\
\text { In their study, Onyiruka et al. (2012) estimated the mean } \\
\text { monthly direct cost of routine diabetes care was } 10,950\end{array}$ \\
\hline
\end{tabular}




\begin{tabular}{|c|c|}
\hline & $\begin{array}{l}\text { Nigerian Naira (US\$73) with the insulin responsible for } 51.1 \% \\
\text { of this cost (126) }\end{array}$ \\
\hline Rwanda & $\begin{array}{l}\text { Rwanda's community-based health insurance system } \\
\text { covered approximately } 80 \% \text { of the population in } 2015-2016 \\
\text { with growth ongoing as Rwanda strives towards universal } \\
\text { health coverage (108, 127). The healthcare system also } \\
\text { covers country's poorest citizens aiming to enhance access } \\
\text { to healthcare for all including medicines } \\
\text { The Rwanda Diabetic Association is active in many areas } \\
\text { across the country to improve the care of patients with } \\
\text { diabetes including T1DM. Activities include running diabetes } \\
\text { awareness programmes, providing relevant information on } \\
\text { diabetes management including medical treatment, training } \\
\text { HCPs, as well as creating a network between key diabetes } \\
\text { care stakeholders and a registry of diabetic patients in } \\
\text { Rwanda. Activities also include providing information to } \\
\text { children and young adults on insulin (128) } \\
\text { Other initiatives to improve the care of patients with T1DM } \\
\text { in Rwanda include the Team Type } 1 \text { Foundation and Abbott } \\
\text { to donate glucose meters as well as nearly } 12 \text { million test } \\
\text { strips }(68)\end{array}$ \\
\hline South Africa & $\begin{array}{l}\text { - The cost of hospitalisation due to diabetes in South Africa } \\
\text { ranges from I\$ } 80 \text { to I\$ } \$ 61 \text { (124), with the treatment of DKA } \\
\text { put a further strain on the system due to late presentations } \\
\text { (14) } \\
\text { - There are concerns glucose testing strips are not available } \\
\text { to every patient and children are being treated with } \\
\text { premixed insulin without access to rapid-acting insulin in } \\
\text { public health facilities (83) }\end{array}$ \\
\hline Sudan & 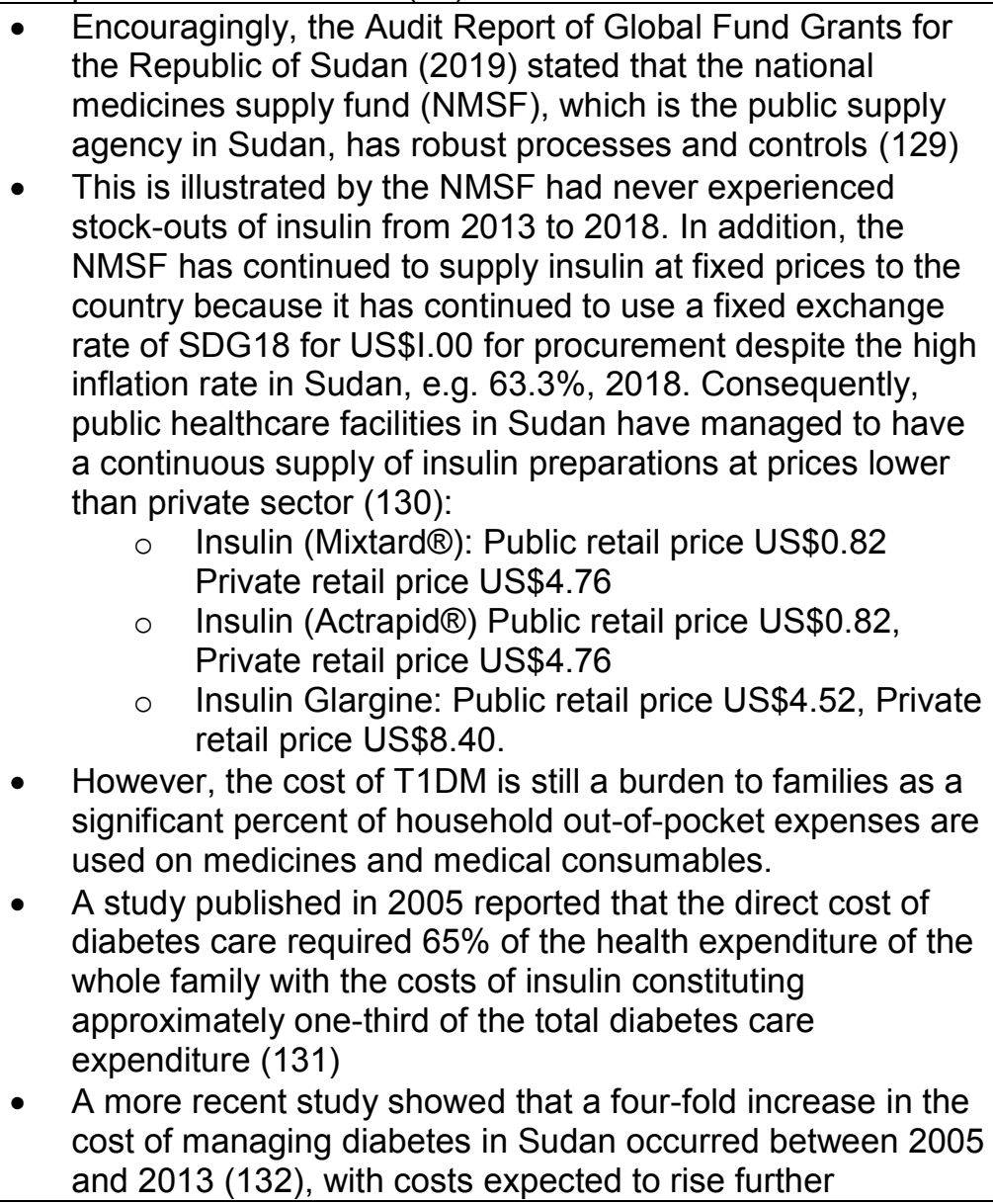 \\
\hline
\end{tabular}




\begin{tabular}{|c|c|}
\hline Tanzania & $\begin{array}{l}\text { Different types of insulin were available in public health facilities } \\
\text { only } 8 \%-17 \% \text { of occasions, with one version of insulin only } \\
\text { available } 34 \% \text { of the time }(10,133) \text {. }\end{array}$ \\
\hline Zambia & $\begin{array}{l}\text { - In Zambia, there are initiatives in place for patients to receive } \\
\text { free or subsidized insulins through the national health } \\
\text { insurance scheme operationalised in } 2020(62) \\
\text { - However, even at an average price of US } \$ 2,00 / \text { vial for } \\
\text { insulin this is still a financial burden in countries where many } \\
\text { patients live on less than US } \$ 1.00 / \text { day (62) } \\
\text { - } \text { Overall insulin (soluble) was available in } 38 \% \text { of facilities } \\
\text { recently surveyed by Mutale et al. (2018) and } 18 \% \text { in rural } \\
\text { facilities (50) } \\
\text { - Kalungia et al. (2017) also confirmed that stock-outs were } \\
\text { high for short acting (83\%) and long acting (69\%) } \\
\text { preparations among the surveyed healthcare facilities (134) } \\
\text { - Kaiser et al. (2019) also found variable availability of insulins } \\
\text { (short acting, intermediate acting and } 30 / 70) \text { ranging from a } \\
\text { low of } 4.6 \% \text { among } 99 \text { surveyed pharmacists in three } \\
\text { adjacent provinces in Zambia up to a } 46.4 \% \text { (135). Median } \\
\text { prices of insulins also varied among the different pharmacies, } \\
\text { e.g. between US } \$ 11.33 \text { to US } \$ 24.79 \text { for intermediate insulin } \\
\text { and US } \$ 16.80 \text { - } \$ \text { US28.82 for insulin } 30 / 70 \text { (135) } \\
\text { The routine availability of glucose strips at public healthcare } \\
\text { facilities is still irregular with issues of affordability } \\
\text { - Socioeconomic circumstances continue to hamper the use of } \\
\text { advanced technologies to manage T1DM in Zambia. Major } \\
\text { barriers to address include not only poverty and poor access } \\
\text { to diabetes care, but also lack of knowledge among } \\
\text { caregivers of T1DM patients which often leads to increased } \\
\text { risk of misdiagnosis and late detection of T1DM (88). }\end{array}$ \\
\hline
\end{tabular}

NB: HCP: Healthcare Professional; T1DM = Type 1 diabetes; T2DM = Type 2 diabetes; PHCs = Primary healthcare centres

Consequently, the principal objective of this paper is to debate ongoing challenges and potential future activities that could be instigated to improve the care of patients with T1DM in Africa. This includes issues surrounding medicine availability and storage along with monitoring equipment and other measures to improve the care of patients with T1DM. There have been a number of systematic reviews and guidelines looking at key issues surrounding the management of patients with diabetes in Africa including the epidemiology, economics and initiatives to strengthen healthcare systems $(1,2$, $19,87,100,114,116,136-139)$. However to date, there have only been a limited number of publications that have comprehensively focused on all aspects of care covering epidemiology, diagnosis, education, and treatment including access to appropriate medicines and monitoring equipment as well as adherence rates. There have also only been a limited number of publications assessing the influence and impact of different interventions to improve the care of patients with T1DM across Africa. In view of this, we sought to document and discuss ongoing and potential activities that could be introduced among all key stakeholder groups across Africa to improve the future care of patients with T1DM. This includes contextualising the findings from a wide range of coauthors from across Africa and wider to provide future guidance.

\section{Methodology}

We initially conducted a narrative review of the literature. In addition, in view of the paucity of publications researching the influence and impact of different interventions to improve the care of patients with T1DM, we consolidated information from the co-authors who are a mixture of senior level personnel from governments and their advisers, clinicians, academia, rational medicine use advisers, HTA personnel, as well as patient organisation personnel, from across Africa and wider. The co-authors were able to provide additional information on the following in their country where known: (i) epidemiology of diabetes especially T1DM; (ii) economics of T1DM including the availability of insulins and co-payment issues with glucose strips and other monitoring equipment; and (iii) current 
facilities for treating patients with T1DM along with current availability of insulins. In addition, suggest potential activities that could be introduced among all key stakeholder groups including governments, physicians, pharmacists, other HCPs as well as patients and their organisations to improve the future care of patients with T1DM in Africa. This included both short- and long-term initiatives building on an understanding of the current situation in their country. The same questions were asked of each coauthor, and the replies were typically consolidated where there were multiple authors in a given country. The findings and suggestions were subsequently consolidated by the principal author (BG) and checked with each co-author during manuscript preparation to add robustness to the findings and suggestions. We have successfully used this approach in previous publications to stimulate debate in other priority healthcare areas and situations to provide future guidance (140-147).

We did not split the African countries into low- or middle-income countries as the issues surrounding the management of patients with T1DM appears to apply across Africa. Consequently, countries can learn from each other. We also did not review each paper to assess whether the presence of diabetes, especially T1DM, had been defined according to WHO and other internationally recognised diagnostic criteria in view of the objectives of this paper $(138,148)$.

\section{Findings and suggested activities}

T1DM is typically diagnosed within primary healthcare centres (PHCs) in the public healthcare system among a number of African countries; alternatively, within district and tertiary hospitals. Generally, most patients with DKA are diagnosed at secondary and tertiary hospitals.

Table 3 contains details of treatments and facilities routinely available within the public healthcare systems among African countries to manage T1DM as well as its complications. As mentioned, the WHO Essential Medicines List (WHO/ EML) lists soluble insulins and intermediate insulins (113). However in their latest guidance on the management of patients with diabetes including T1DM, the WHO suggests long-acting insulin analogues can be used to control blood glucose levels in patients with T1DM who have frequent severe hypoglycaemia with human insulin (149). This though will be an issue for many African countries given considerable differences in costs and existing concerns with the routine availability of NPH insulins $(98,150)$.

Table 3 - Facilities and treatments available in the public healthcare system among African countries to manage T1DM and its complications

\begin{tabular}{|c|c|}
\hline Country & Treatments and Facilities \\
\hline Botswana & $\begin{array}{l}\text { - Random blood glucose within public healthcare facilities including PHCs } \\
\text { is part and parcel of the initial evaluation when patients first present with } \\
\text { suspected diabetes in Botswana } \\
\text { Insulins routinely available among public healthcare facilities in } \\
\text { Botswana include: } \\
\text { Short-acting regular human insulins } \\
\text { Actrapid } \\
\text { Rapid-acting analogue insulins } \\
\text { Aspart (NovoRapid) } \\
\text { Glulisine [Apidra] } \\
\text { Intermediate-acting (basal) human insulins } \\
\text { NPH - neutral protamine Hagedorn } \\
\text { Long-acting (basal) analogue insulins } \\
\text { Glargine [Lantus] } \\
\text { Pre-mixed human (biphasic) insulins } \\
\text { 30\% Regular + 70\% NPH [Actraphane] } \\
\text { Pre-mixed analogue insulins } \\
\text { Rapid-acting plus basal (NPH) } \\
\text { Biphasic aspart [NovoMix-] } \\
\text { Biphasic lispro [Humalog Mix } 25] \\
\text { NB: Most of these insulins are available in specialized diabetes clinics. In } \\
\text { non-specialised clinics, only a few insulins are available on specialist } \\
\text { prescription forms (special order- NovoMix, NovoRapid). }\end{array}$ \\
\hline
\end{tabular}




\begin{tabular}{|c|c|}
\hline & $\begin{array}{l}\text { - Treatments available to help manage the complications of T1DM within } \\
\text { the public healthcare system include: } \\
\circ \text { Medicines, e.g. blood pressure medicines - routinely available } \\
\text { free of charge within public healthcare facilities } \\
\circ \text { Procedures: retinal photocoagulation, renal replacement therapy } \\
\text { by dialysis (both haemodialysis and peritoneal dialysis are } \\
\text { available in tertiary healthcare facilities with the costs covered by } \\
\text { the Government of Botswana), and renal replacement therapy } \\
\text { by transplantation (currently performed outside of Botswana with } \\
\text { the costs covered by government); coronary artery disease } \\
\text { treatment is also available for diabetes patients where pertinent } \\
\text { Basic technologies: Blood glucose measurement, Urine strips for } \\
\text { glucose and ketone measurements, HbA1c }\end{array}$ \\
\hline Cameroon & $\begin{array}{l}\text { - Patients are routinely seen by nurses and general practitioners in the } \\
\text { Cameroon in PHCs, with specialist care only available at regional or } \\
\text { reference hospitals } \\
\text { - } \\
\text { All care is currently out of pocket. Micro insurance schemes do not cover } \\
\text { medical costs for diabetes or related conditions. } \\
\text { Random blood sugar, fasting blood sugar, and urinalysis are routine } \\
\text { tests to assess the care of patients with T1DM. HbA1c is not available. } \\
\text { - Available options for insulin include INSULET RAPID (DCI: INSULINE } \\
\text { GLARGINE } 1000 \mathrm{UI} / \mathrm{mL} \text { ) ; INSULET MIX (DCI: INSULINE GLARGINE } \\
1000 \mathrm{UI} / \mathrm{mL} \text { ); and INSULET NPH (DCI : INSULINE GLARGINE } 100 \\
\mathrm{UI} / \mathrm{mL} \text { ) } \\
\text { Chronic disease support groups known as Non-Communicable Disease } \\
\text { clinics are common in Cameroon and provide monthly services to } \\
\text { patients mostly for check ups }\end{array}$ \\
\hline Ghana & $\begin{array}{l}\text { - Insulins currently available in the Ghana EML for prescribing in PHCs } \\
\text { include Insulin Aspart, Insulin Detemir, Insulin Glargine, Insulin Lispro, } \\
\text { Insulin Soluble, Insulin Isophane (NPH) and Premixed (mixture of soluble } \\
\text { insulin and intermediate NPH insulin in a } 30: 70 \text { ratio) } \\
\text { - The only insulins available under the National Health Insurance Scheme } \\
\text { (NHIS) include insulin soluble, NPH and Premixed (30/70) while the rest } \\
\text { are purchased out of pocket when prescribed (151) } \\
\text { - Whilst some basic laboratory tests such as fasting blood glucose are } \\
\text { provided under the NHIS, other relevant routine tests such as HbA1c } \\
\text { and other supplies such as glucometer test strips and insulin syringes } \\
\text { and needles currently have to be paid for out-of-pocket } \\
\text { - Patients in PHCs are typically reviewed every 2-3 months and given } \\
\text { refills of their insulin based on current availability at PHCs. However, not } \\
\text { all health centres have dieticians and patients have to typically rely on } \\
\text { their physician or nurse for food/nutrition advice } \\
\text { Complicated cases of T1DM requiring advanced specialist care including } \\
\text { dialysis, renal replacement therapy are referred to one of the few } \\
\text { available tertiary hospitals. Advanced care is not covered by the NHIS } \\
\text { and therefore service are paid for out of pocket }\end{array}$ \\
\hline $\begin{array}{l}\text { Kingdom of } \\
\text { Eswatini } \\
\text { (Swaziland) }\end{array}$ & 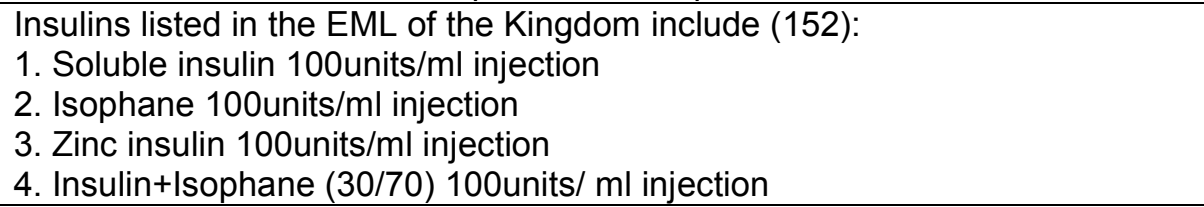 \\
\hline Namibia & $\begin{array}{l}\text { - A wide range of insulins including soluble and long acting insulins are } \\
\text { available to the public via PHCs financed by the government of the } \\
\text { Republic of Namibia. }\end{array}$ \\
\hline Nigeria & $\begin{array}{l}\text { - Short acting or meal time insulins, premixed insulin and insulin glargine } \\
\text { are currently contained in the Nigerian EML. However, there are } \\
\text { problems with the availability and affordability of insulin glargine } \\
\text { - The Diabetic Association of Nigeria has been involved with the } \\
\text { development of practice guidelines in Nigeria to improve the care of }\end{array}$ \\
\hline
\end{tabular}




\begin{tabular}{|c|c|}
\hline & $\begin{array}{l}\text { patients with diabetes including patients managed in PHCs. The } \\
\text { association has also had agreements with pharmaceutical companies to } \\
\text { reduce the cost of their medicines to increase access and usage } \\
\text { There is typically routine monitoring of blood glucose using glucometer } \\
\text { and laboratory testing in patients treated in secondary and tertiary } \\
\text { hospitals. Routine monitoring of HbA1c is typically too expensive for } \\
\text { most patients due to high co-payment levels in Nigeria } \\
\text { There are typically yearly referrals to eye clinics for assessment and } \\
\text { treatment as well as routine treatment for systemic hypertension and } \\
\text { dyslipidaemia when this occurs. Dialysis facilities are available but can } \\
\text { be problematic in view of the costs involved }\end{array}$ \\
\hline South Africa & 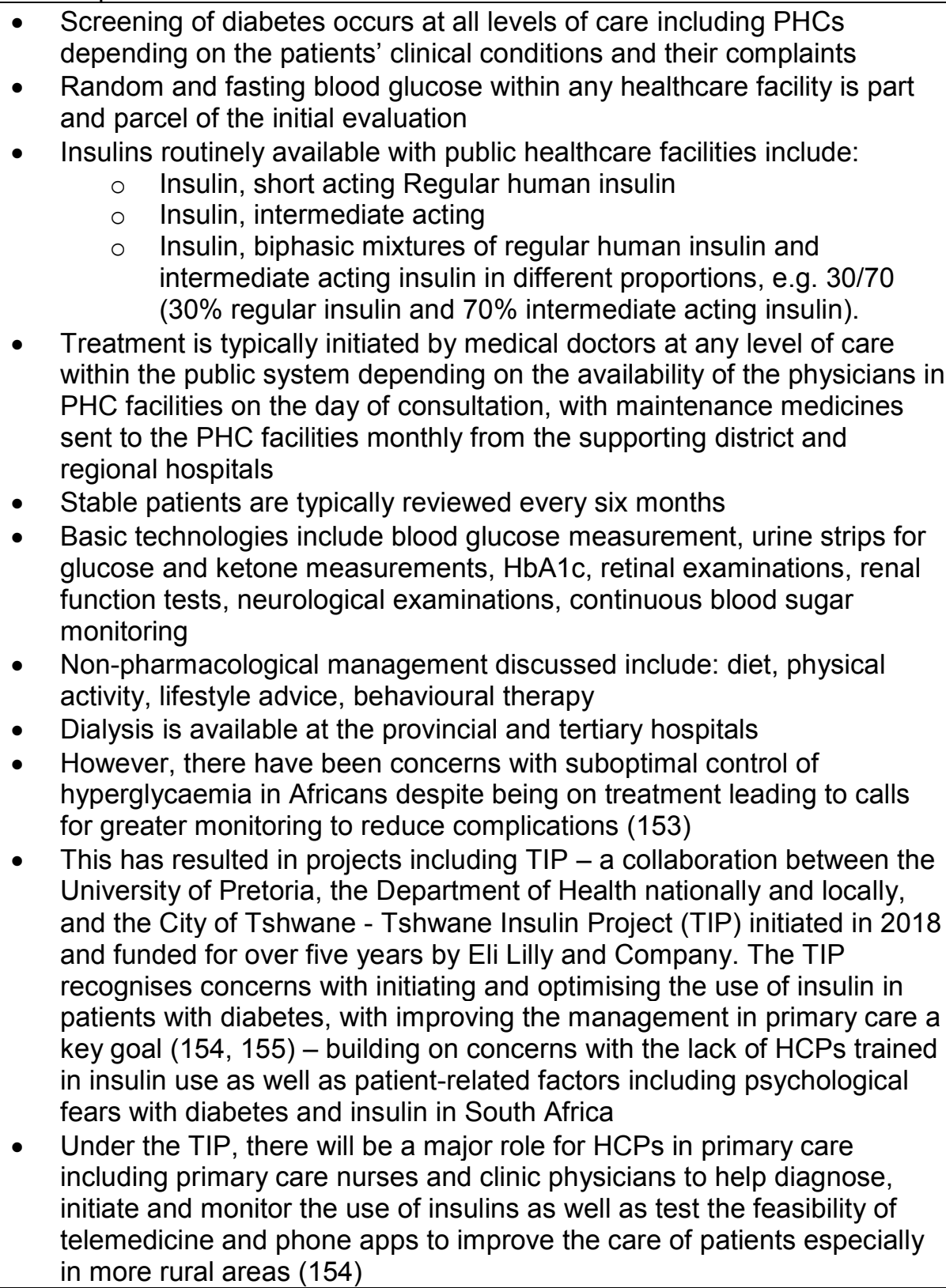 \\
\hline Sudan & $\begin{array}{l}\text { Insulin preparations listed on the Sudan NEML are (156): } \\
\text { - Short acting (soluble) Insulin } \\
\text { - Insulin Lispro } \\
\text { - Insulin mixed } \\
\text { Based on the actual need as specified by the practitioners, NMSF covers } \\
\text { only three of the insulin preparations included in the EML as follow: }\end{array}$ \\
\hline
\end{tabular}




\begin{tabular}{|c|c|}
\hline & $\begin{array}{ll}\text { - } & \text { Insulin (Mixtard } 囚) \\
\text { - } & \text { Insulin (Actrapid } 囚) \\
\text { - } & \text { Insulin Glargine }\end{array}$ \\
\hline Zambia & $\begin{array}{l}\text { - Insulin preparations listed on the Zambia EML are: } \\
\circ \quad \text { Short acting (soluble) Insulin } \\
\circ \quad \text { Isophane Insulin, Biphasic Insulin } \\
\circ \text { Actraphane or mixtard (30/70) } \\
\circ \quad \text { Long acting insulins } \\
\text { In Zambia, healthcare interventions available to prevent and manage } \\
\text { complications include: } \\
\circ \quad \text { Routine monitoring of blood levels as well as BP } \\
\text { measurement/treatment across all levels of public healthcare } \\
\text { including PHCs } \\
\text { At level } 2 \text { and } 3 \text { (district and tertiary hospitals), monitoring of patients } \\
\text { regarding the development of retinopathy, neuropathy, etc., typically } \\
\text { takes place } \\
\circ \quad \text { Dialysis for patients with nephropathy is mostly available at tertiary } \\
\text { level hospitals } \\
\quad \text { Referral and treatment of diabetes ketoacidosis takes place at level } \\
2 \text { and } 3 \text { hospitals } \\
\text { Diabetes clinics manned by specialist physician established at level } 2 \\
\text { and } 3 \text { hospitals }\end{array}$ \\
\hline Zimbabwe & $\begin{array}{l}\text { - Listed in the Zimbabwe EML include: } \\
\text { Bolus insulins, e.g. rapid and short acting insulins including } \\
\text { ASPART and ACTRAPID } \\
\text { Intermediate and long acting insulin analogues including } \\
\text { biphasic insulins (30/70), PROTAPHANE as well as insulin } \\
\text { glargine and degludec } \\
\text { - T1DM is typically treated starting in district hospitals. Routine laboratory } \\
\text { testing facilities are available but there are concerns with the lack of } \\
\text { consumables. In addition, the cost of tests is a deterrent for most } \\
\text { diabetic patients in public institutions compromising their chronic care } \\
\text { Complications associated with T1DM are assessed as part of routine } \\
\text { care by physicians at eye and diabetic clinics including those in tertiary } \\
\text { level facilities } \\
\text { Dialysis is available at some provincial hospitals as well as in all } 5 \\
\text { central hospitals in the country }\end{array}$ \\
\hline
\end{tabular}

NB: EML = Essential Medicines List; T1DM = Type 1 diabetes; PHCs = Primary healthcare centres

Boxes 1 to 6 contain suggested activities from the co-authors that can be undertaken to improve the care and outcomes of patients with T1DM in Africa, Activities for healthcare professional groups and patients/ patient organisations are broken down into short and longer term activities. 


\section{Leadership and governance}

- Commit at the highest level to make quality T1DM healthcare services and medication based on current guidelines within countries available for all T1DM patients. In the longer term, such services should be free at the point of delivery irrespective of the ability of patients or their families to pay for such services

- Instigate initiatives to highlight to key government and other officials that T1DM is a public health concern across Africa. As part of these initiatives, include primary healthcare and disease prevention as part of a national health strategy to reduce morbidity and mortality due to NCDs

- Institutionalise routine screening for potential patients with T1DM in all healthcare facilities including both symptomatic and asymptomatic patients, and make screening free of charge. A key area will be primary healthcare centres within public healthcare systems as opposed to hospitals and specialist clinics

- Provide incentives for increasing the number of endocrinologists within a country where pertinent. In the short term, this could include using International aid to boost the number of endocrinologists within a country

- Introduce/ expand effective chronic disease management systems of care for patients with T1DM to improve the efficiency of care delivery

- Strengthen policy and systems towards T1DM management including encouraging adherence to WHO guidance as well as regular updates on country guidelines and NCD policies that incorporate T1DM. In addition, encourage operational research to monitor improvements in care delivery. As part of this, seek to provide direct economic, medical and social support for families with a child with T1DM

- Restructure where pertinent inventory management and procurement systems for insulin and its accessory devices nationally and among PHCs to ensure routine availability and accessibility to all types of insulin necessary for the effective management of patients with T1DM

\section{Health care workforce}

- Increase recruitment/ retention of general practitioners, family physicians with an interest in diabetes, dieticians, specialist pharmacists, and clinical psychologist with a special focus on $\mathrm{PHCs}$ for comprehensive clinical management in line with a growing focus on PHCs to diagnose and manage patients with T1DM in Africa. This alongside greater recruitment and retention of endocrinologists in Africa. As a result, improve and attain a good distribution of a relevant healthcare workforce across the spectrum

- Task shifting to enable pharmacists, nurses and community healthcare workers help run diabetes clinics and educational initiatives in both urban and rural settings

- Introduce a syllabus for HCPs on NCDs including T1DM so that all staff including clinical and non clinical staff can create a common language and framework for managing patients with T1DM

- Following this, regular continuous training and performance development for of all HCPs to improve their diagnosis and care of patients with TIDM including prevention and treatment of potential complications. This includes information of the mechanism of action of medicines and potential adverse events - and as part of this look to make available charts on how to manage T1DM including self-monitoring and potential complications

\section{Medical products and technologies}

- Improve the availability and supply of products and technologies used for T1DM management including routine/ consistent availability of insulins on the WHO EML as well as making fasting blood sugar levels and $\mathrm{HbA} 1 \mathrm{c}$ testing more affordable for patients. This can be through collaborations with NGOs especially around the free provision of glucometers and test strips

- In the longer term seek to include routine availability of long acting analogues for suitable patients with the increasing availability of biosimilars

- Explore solar-dependent refrigeration for insulin preparations at the household level especially in rural settings

- Consider non-invasive methods of glucose monitoring to improve compliance to self-care modalities 
- Utilise cost-effective interventions

- Commit in the longer term for governments and health authorities to use HTA as part of decision-making processes to guide investment and funding decisions based on the efficacy, effectiveness, safety and cost-effectiveness of different technologies

Financing

- Improve healthcare financing towards T1DM management to reduce current morbidity and mortality rates. This can include expansion of health insurance towards universal access in a number of African countries

- This includes reducing or negating out-of-pocket payments and co-payments for insulin as well as for monitoring including glucose strips

- Improve medicine and product quality, access and pricing mechanisms to control for substandard products as well as improve prices paid for insulins given appreciable price variations for insulins and other medicines to manage patients with T1DM across Africa and within countries

- Incentivise pharmacists as well other HCPs to establish medicines management centres in rural settings

- Research and Innovation

- Invest in epidemiological research where this is currently lacking including potentially the establishment of a national surveillance system/ databases for patients with T1DM to improve monitoring and evaluation of care delivery. This can include the introduction of IT systems/ electronic medical records to enable monitoring of care at the patient level

- Invest in HTA research where this is lacking to enable greater critique of evidence based potential alternatives within finite resources to improve efficient use of resources

- Invest in research surrounding possible innovative solutions including cost-effective solutions

- Encourage greater collaboration and linkage between research institutions, academia and policy makers

NB: EML = Essential Medicines List; $\mathrm{HCPs}=$ Healthcare professionals; $\mathrm{HTA}=$ Health Technology Assessment: T1DM = Type 1 diabetes; $\mathrm{PHCs}=$ Primary healthcare centres; NCDs = Non-communicable diseases; $\mathrm{WHO}=$ World Health Organisation

Box 2 - Physicians (hospital and ambulatory care)

\section{Short term}

- Introduce greater opportunities for training and re-training of ambulatory care physicians in the management of patients with T1DM starting in pharmacy and medical schools and progressing to in-service training. This can also include greater knowledge surrounding key issues such as adherence to the medicines prescribed for both T1DM and its complications as well as the need for greater psychological support to improve patient care

- Work with key agencies to develop local evidence-based guidelines for the management of patients with T1DM. These can subsequently be used as a basis for future quality improvement programmes

- Encourage more specialist doctors in fields such as endocrinology to contribute to better of patients with T1DM across Africa

- Work with others to seek to improve the availability of medicines for all T1DM patients

- Work with others to address ongoing bottlenecks in the pharmaceutical supply chain of T1DM medicines and products as well as working with others to help ensure quality and affordable medicines and technologies

\section{Longer term}

- Seek to attain a good distribution of physicians across the spectrum of health service provision, and geographical areas (rural and urban) settings

- Regular updating of guidelines when any changes in available medicines and technologies NB: T1DM = Type 1 diabetes 


\section{Short term}

- Continuous training and re-training of pharmacists regarding the management and education of patients with T1DM starting in pharmacy school

- Improve the participation and role of community pharmacists in providing care to patients with T1DM including counselling especially dealing with key issues such as re-fill prescriptions, insulins and needles as well as glucose monitoring. Include patient education to empower them to address key issues such as adherence, diet and lifestyles as well as concerns with the impact of T1DM on their quality of life

- Enhance the role of pharmacists in pharmacovigilance, medication error reporting and quality assurance of medicines and products used in T1DM. This can include the employment of Doctor of Pharmacy graduates (where these exist) in the public healthcare sector to improve patient-centred care

- Integrate and accredit community pharmacy services within national health insurance schemes. Services can be enhanced by introducing additional pharmacist training on the care of patients with diabetes. Look to include mandatory continuous performance development programmes

- Establishment and strengthening of medicines information services to all healthcare professionals as well as patients

- Encourage proactive data collection, analysis and feedback to both patients and healthcare providers at the facility level in terms of agreed diabetes management monitoring indicators

\section{Longer term}

- Conduct research and development of novel treatment modalities, medicines and products, including pharmacogenetics of T1DM in the population

- Provide incentives and opportunities for operational research on NCDs such as T1DM

- Potentially seek to establish pharmacist-led diabetic services at all levels of healthcare to address concerns with available facilities and personnel

NB: T1DM = Type 1 diabetes; NCDs = Non-communicable diseases

Box $4-$ Healthcare professionals in ambulatory and hospital care including nurse practitioners

\section{Short term}

- Enhance competences and skills of the healthcare workforce to better diagnose and manage patients with T1DM through improved training including in-service training. Look to include the development and introduction of dedicated diabetic nurse educators

- Seek to train ambulatory and acute hospital care staff regarding any relevant advances and technologies used in the care of patients with T1DM

- Routinely provide relevant equipment for their roles

Longer term

- Undertake quality improvement research to address gaps in strategies and technical aspects to improve future service delivery

NB: T1DM = Type 1 diabetes

Box 5. Health technology (other than pharmaceutical therapy)

\section{Short term}

- Continuous training and re-training of clinical technologists regarding the management of patients with diabetes

- Enhance the role of clinical technologists in surveillance, quality assurance of results and products used in the management of patients with T1DM. This can include the employment of clinical technology graduates (where these exist) in the public healthcare sector to improve patient-centred care

- Integrate and accredit community laboratory services within national health insurance schemes, enhanced by the introduction of additional training on the care of patients with diabetes. This can ultimately include mandatory continuous performance development programmes

\section{Longer term}

- Involvement of biomedical engineers for development of newer diagnostic techniques 
- Conduct research and development of novel diagnostic modalities that are affordable and can improve the management of patients with T1DM efficiently (such as continuous glucose monitoring system)

- Provide incentives and opportunities for operational research on NCDs such as T1DM

- Involvement of experts in Health Technology Assessment for measuring the impact of different health technologies on the future management of patients with TIDM

NB: T1DM = Type 1 diabetes

Box 6 - Suggested activities among patients/ support services

\section{Short term}

- Encourage the development and expansion of patient support networks to enhance the identification and subsequent management of patients with T1DM including the importance of diet and physical activities as well as the need for psychological management for patients with T1DM. For instance, in Zambia, the Diabetes Association of Zambia has been key in encouraging and engaging key stakeholder groups on diabetes matters, with the Diabetes Association in Nigeria playing a key role in guideline development and securing lower prices for medicines

- Undertake health education to communities to increase awareness, access to care and social support for patients with T1DM. This can include establishment of youth groups for children and adolescents in every community. Such groups can promote self care and reduce any stigmatization associated with T1DM through group sharing of experiences

\section{Longer term}

- Instigate comprehensive adolescent health initiatives as part of patient education programmes that help to reduce the complications of T1DM including DKA, neuropathy, nephropathy and CV diseases

- Developing pertinent initiatives among T1DM patients and their families, particularly among adolescents, to ensure acceptance of diabetes and ant diabetes care plan as part of their lives - viewing diabetes as manageable and as their responsibility. As part of this, work with patients and patient organisations to gain valuable information on diabetes and diabetes management to improve future care (157)

- Encourage greater patient engagement and involvement in the health technology assessment process

$\underline{\text { NB: }}$ CV =cardiovascular; DKA = diabetic ketoacidosis; $\underline{\text { T1DM }=\text { Type } 1 \text { diabetes }}$

\section{Discussion and next steps}

There is a growing prevalence of patients with T1DM across Africa. Increased morbidity and mortality can be expected in view of the number of patients not diagnosed or misdiagnosed, concerns with the routine availability of insulins even those within country's EML, and high co-payments for insulins in a number of African countries. High co-payments for glucose monitoring equipment and testing strips across many African countries add to the patient's and families' financial burden. The consequences are potentially catastrophic for families. There are also concerns regarding the lack of HCP support including education and psychosocial support. Specialists are also needed to help improve the management of patients with T1DM across Africa. This includes help with patients coming to terms with their disease as well as helping with adherence to the medicines prescribed to reduce the complications of T1DM, which include DKA, hypoglycaemia and microvascular complications. Encouragingly, we are seeing patient organisations and NGOs including the IDF playing an increasing role among African countries to improve the care of patients with T1DM. This is likely to grow. A greater focus is also ongoing among African countries to improve the management of patients with NCDs.

Boxes 1 to 6 provide suggestions for governments as well as all key stakeholder groups to improve the care of patients with T1DM both in the short and longer term. We will be monitoring this progress in the future as countries seek to improve the care of their patients with T1DM. Diagnosis and management rates for patients with diabetes including T1DM need to be appreciably improved across Africa to achieve the World Health Organisation's (WHO) $25 \times 25$ Global Action Plan (2013) as well as Sustainable Development Goal (SDG) 3 goal to reduce premature deaths due to NCDs across countries by a third by 2030 (158-162). With respect to increasing the routine availability of insulins alongside reducing co-payments where concerns, it is better for countries to focus initially on 
increasing the availability of NPH insulins as opposed to procuring more expensive insulin analogues apart from those necessary to treat insulin resistant patients. This is because a number of published studies from academic and HTA units have not demonstrated significant differences between NPH and the more expensive long acting insulins in terms of reducing hypoglycaemia episodes or on patient's quality of life (163-170). However, this finding was not universal (171). More recently, long acting insulins have been recommended as second line in patients who are allergic to conventional insulins or have failed to have their T1DM controlled with conventional insulins $(149,172,173)$. First though the availability of WHO EML recommended insulins (113) needs to become routine at affordable prices to patients; preferably free-of-charge. As part of this, African governments need to see how they can procure insulins and monitoring technologies including insulin strips at more affordable prices for patients where there are concerns with high co-payment levels. The private sector can play its role by lowering prices and/ or enhancing access programmes in Africa, building on existing initiatives $(61,94)$. In addition in their procurement negotiations, African countries need to use their own and surrounding countries' existing price data to negotiate improved prices with the potential for developing mechanisms to foster competition and secure supplies of insulin with only a limited number of companies supplying them with insulin (100). In time as more biosimilars become available, increased competition should lead to lower prices and greater availability across Africa (building on Table 3) (98). Improved forecasting and distribution systems should help reduce stockouts, building on recent initiatives in South Africa (174).

We are aware of a number of limitations with our study. This includes the fact that we did not undertake a systematic review for the reasons already mentioned. We are also aware that there have been a paucity of studies assessing the influence and impact of interventions to improve the care of patients with T1DM among African countries. However, we have incorporated the views of a wide variety of senior level personnel from across Africa with experience of managing, organising, researching or educating others about the care of patients with T1DM to help address such concerns. Consequently, we believe our findings and suggestions are robust.

\section{Conclusion}

The improved management of patients with T1DM across Africa is starting to be addressed as countries develop and refine their action plans to improve the care of patients with NCDs as part of SDG goals, with further suggestions contained in Boxes 1 to 6 . However, there are still considerable concerns and all key stakeholder groups need to work together to appreciably improve the future care and self care of patients with T1DM across Africa.

We will be monitoring developments regarding the future management of T1DM among African countries, including the impact of interventions to improve their care. In addition, it is important to rapidly publish any findings so that African countries can learn from each other, and we will be seeking to undertake this.

\section{Conflicts of interest and funding}

The co-authors declare that the research was conducted in the absence of any commercial or financial relationships that could be construed as a potential conflict of interest. However, a number of co-authors are employed by national or regional governments in Ministries of Health or are advisers to them.

There was no funding for this paper.

\section{ORCID Numbers}

Brian Godman http://orcid.org/0000-0001-6539-6972

Julius C. Mwita http://orcid.org/0000-0002-5947-3684

Godfrey Mutashambara Rwegerera http://orcid.org/0000-0002-5896-

6065

Israel Sefah http://orcid.org/0000-0001-6963-0519

Dan Kibuule http://orcid.org/0000-0002-6908-2177

Francis Kalemeera http://orcid.org/0000-0002-4320-5087

Joseph Fadare http://orcid.org/0000-0002-5641-1402 
Olayinka O. Ogunleye http://orcid.org/0000-0002-8921-1909

Enos M. Rampamba http://orcid.org/0000-0002-3492-9104

Aubrey Kalungia http://orcid.org/0000-0003-2554-1236

Trust Zaranyika http://orcid.org/0000-0003-4363-7709

Nyasha Masuka http://orcid.org/0000-0003-4653-8626

Ruaraidh Hill http://orcid.org/0000-0002-2801-0505

Amanj Kurdi http://orcid.org/0000-0001-5036-1988

Stephen Campbell http://orcid.org/0000-0002-2328-4136

Johanna C. Meyer http://orcid.org/0000-0003-0462-5713

\section{References}

1. Atun R, Davies JI, Gale EAM, Barnighausen T, Beran D, Kengne AP, et al. Diabetes in subSaharan Africa: from clinical care to health policy. The lancet Diabetes \& endocrinology.

2017;5(8):622-67.

2. Mapa-Tassou C, Katte JC, Mba Maadjhou C, Mbanya JC. Economic Impact of Diabetes in

Africa. Current diabetes reports. 2019;19(2):5.

3. WHO. GLOBAL REPORT ON DIABETES. 2016. Available at URL:

http://apps.who.int/iris/bitstream/10665/204871/1/9789241565257_eng.pdf?ua=1.

4. International Diabetes Feceration. IDF Africa Members. 2019. Available at URL:

https://idf.org/our-network/regions-members/africa/members/25-south-africa.html.

5. IDF. IDF DIABETES ATLAS Ninth Edition Africa. 2019. Available at URL:

https://diabetesatlas.org/upload/resources/2019/2019_regional_factsheet.pdf.

6. Elliot J, Besançon S, Sachs J. Almost 100 years after it was discovered, let's make access to insulin a reality in Africa! 2016. Available at URL: https://ideas4development.org/en/almost-100-yearsafter-it-was-discovered-lets-make-access-to-insulin-a-reality-in-africa/.

7. Godman B, Basu D, Pillay Y, Mwita JC, Rwegerera GM, Anand Paramadhas BD et al. Review of ongoing activities and challenges to improve the care of patients with Type 2 diabetes across Africa and the implications for the future. 2020. In Press Frontiers in Pharmacology.

8. Pambou Damiens A, Ganga-Zandzou PS, Tsoucka Ibounde E, Kayemba-Kay's S, Baye E, Biloghe $\mathrm{P}$, et al. Type 1 diabetes mellitus in Gabon: A study of epidemiological aspects. International journal of pediatrics \& adolescent medicine. 2019;6(3):87-91.

9. Hall V, Thomsen RW, Henriksen O, Lohse N. Diabetes in Sub Saharan Africa 1999-2011: Epidemiology and public health implications. a systematic review. BMC public health. 2011;11:56410. Pastakia SD, Pekny CR, Manyara SM, Fischer L. Diabetes in sub-Saharan Africa - from policy to practice to progress: targeting the existing gaps for future care for diabetes. Diabetes Metab Syndr Obes. 2017;10:247-63.

11. Uloko AE, Ofoegbu EN, Chinenye S, Fasanmade OA, Fasanmade AA, Ogbera AO, et al. Profile of Nigerians with diabetes mellitus - Diabcare Nigeria study group (2008): Results of a multicenter study. Indian J Endocrinol Metab. 2012;16(4):558-64.

12. International Diabetes Federation. IDF Atlas Ninth Edition. 2019. Available at URL: https://diabetesatlas.org/upload/resources/material/20200106_152211_IDFATLAS9e-final-web.pdf.

13. Niba LL. Determinants of outcome of children with type 1 diabetes in the North West Region of Cameroon. 2016. Available at URL: https://edoc.ub.uni-muenchen.de/20100/7/Niba_Loveline.pdf. 14. Reddy Y, Gannie Y, Pillay K. Characteristics of children presenting with newly diagnosed type1 diabetes. SAJCH. 2013; 7(2).

15. Balcha SA, Phillips DIW, Trimble ER. Type 1 Diabetes in a Resource-Poor Setting: Malnutrition Related, Malnutrition Modified, or Just Diabetes? Current diabetes reports. 2018;18(7):47.

16. Marshall SL, Edidin D, Arena VC, Becker DJ, Bunker CH, Gishoma C, et al. Prevalence and incidence of clinically recognized cases of Type 1 diabetes in children and adolescents in Rwanda, Africa. Diabetic medicine. 2015;32(9):1186-92.

17. Marshall SL, Edidin DV, Arena VC, Becker DJ, Bunker CH, Gishoma C, et al. Glucose control in Rwandan youth with type 1 diabetes following establishment of systematic, $\mathrm{HbA} 1 \mathrm{c}$ based, care and education. Diabetes research and clinical practice. 2015;107(1):113-22.

18. Padoa CJ, Rheeder P, Pirie FJ, Motala AA, van Dyk JC, Crowther NJ. Identification of a subgroup of black South Africans with type 1 diabetes who are older at diagnosis but have lower levels of glutamic acid decarboxylase and islet antigen 2 autoantibodies. Diabetic medicine. 2019. 19. Patterson CC, Karuranga S, Salpea P, Saeedi P, Dahlquist G, Soltesz G, et al. Worldwide estimates of incidence, prevalence and mortality of type 1 diabetes in children and adolescents: 
Results from the International Diabetes Federation Diabetes Atlas, 9th edition. Diabetes research and clinical practice. 2019;157:107842.

20. Bahendeka SK. Diabetes in sub-Saharan Africa: let us not forget type 1. The lancet Diabetes \& endocrinology. 2017;5(8):575-7.

21. International Diabetes Federation. IDF Ninth Edition - Country Summary Table. 2019.

Available at URL: https://diabetesatlas.org/en/resources/.

22. Jasem D, Majaliwa ES, Ramaiya K, Najem S, Swai ABM, Ludvigsson J. Incidence, prevalence and clinical manifestations at onset of juvenile diabetes in Tanzania. Diabetes research and clinical practice. 2019;156:107817.

23. da Rocha Fernandes J, Ogurtsova K, Linnenkamp U, Guariguata L, Seuring T, Zhang P, et al. IDF Diabetes Atlas estimates of 2014 global health expenditures on diabetes. Diabetes research and clinical practice. 2016;117:48-54.

24. Pei F. Managing Diabetes in Urban Ghana: Is it Affordable? 2015. Available at URL: https://dukespace.lib.duke.edu/dspace/bitstream/handle/10161/10014/Pei_duke_0066N_12921.pdf?s equence $=1$ \&isAllowed $=y$.

25. Amoah AG, Owusu SK, Adjei S. Diabetes in Ghana: a community based prevalence study in Greater Accra. Diabetes research and clinical practice. 2002;56(3):197-205.

26. International Diabetes Federation. IDF Africa Members - Ghana. 2017. Available at URL: https://idf.org/our-network/regions-members/africa/members/11-ghana.html.

27. IDF. Middle East and North Africa. 2019. Available at URL: https://idf.org/our-network/regionsmembers/middle-east-and-north-africa/members/41-morocco.html.

28. Dinar Y, Belahsen R. Diabetes Mellitus in Morocco: Situation and Challenges of Diabetes Care. Journal of Scientific Research \& Reports. 2014; 3(19): 2477-2485.

29. Chetoui A, Kaoutar K, Kardoudi A, Boutahar K, Chigr F, Najimi M. Epidemiology of diabetes in Morocco: review of data, analysis and perspectives. International Journal of Scientific \& Engineering Research 2018; 9 (12): 1310 - 16.

30. Adekanmbi VT, Uthman OA, Erqou S, Echouffo-Tcheugui JB, Harhay MN, Harhay MO. Epidemiology of prediabetes and diabetes in Namibia, Africa: A multilevel analysis. Journal of diabetes. 2019;11(2):161-72.

31. Ugege O, Ibitoye PK, Jiya NM. Childhood diabetes mellitus in sokoto, north-western Nigeria: A ten year review. Sahel Med J. 2013;16:97-101.

32. Adeleke SI, Asani MO, Belonwu RO, Gwarzo GD, Farouk ZL. Childhood diabetes mellitus in Kano, North West, Nigeria. Nigerian journal of medicine. 2010;19(2):145-7.

33. Ibekwe M U, Ibekwe R C. Pattern of Type 1 Diabetes Mellitus in Abakaliki, Southeastern, Nigeria. Pediatr Oncall J. 2011;8: 59-62.

34. Umar UI. Pattern of presentation of Type 1 diabetic patients in Kano, Nigeria. Niger J Basic Clin Sci 2016;13:85-8.

35. John C, Abok II, Yilgwan C. Clinical profile of childhood type 1 diabetes in Jos, Nigeria.

African Journal of Diabetes Medicine. 2013; 21 (1): 11-13.

36. Nsabimana J de Dieu. Diabetes prevalence in Rwanda at 3\% - MoH. 2019. Available at URL: https://www.newtimes.co.rw/news/diabetes-prevalence-rwanda-3-moh.

37. Mutyambizi C, Booysen F, Stokes A, Pavlova M, Groot W. Lifestyle and socio-economic inequalities in diabetes prevalence in South Africa: A decomposition analysis. PloS one. 2019;14(1):e0211208.

38. Ekpebegh CO, Longo-Mbenza B. Clinical, immunologic and insulin secretory characteristics of young black South African patients with diabetes: Hospital based single centre study. Diabetes research and clinical practice. 2013;99(3):380-4.

39. Elamin A, Ghalib M, Eltayeb B, Tuvemo T. High incidence of type 1 diabetes mellitus in Sudanese children, 1991-1995. Annals of Saudi medicine. 1997;17(4):478-80.

40. World Health Organisation. Country Profile - Zambia. 2019. Available at URL: https://www.who.int/diabetes/country-profiles/zmb en.pdf?ua=1.

41. Mutowo M, Gowda U, Mangwiro JC, Lorgelly P, Owen A, Renzaho A. Prevalence of diabetes in Zimbabwe: a systematic review with meta-analysis. International journal of public health. 2015;60(1):1-11.

42. Pirie FJ, Pegoraro R, Motala AA, Rauff S, Rom L, Govender T, et al. Toll-like receptor 3 gene polymorphisms in South African Blacks with type 1 diabetes. Tissue Antigens. 2005;66(2):125-30.

43. Piloya-Were T, Sunni M, Ogle GD, Moran A. Childhood diabetes in Africa. Current opinion in endocrinology, diabetes, and obesity. 2016;23(4):306-11. 
44. Chikani UN, Bisi-Onyemaechi Al, Oguonu T, Ugege SM, Ogugua C. Childhood diabetes: a myth or reality?- perception of the public from a low-income country: a cross-sectional study. BMC public health. 2018;18(1):852.

45. Panz VR, Kalk WJ, Zouvanis M, Joffe BI. Distribution of autoantibodies to glutamic acid decarboxylase across the spectrum of diabetes mellitus seen in South Africa. Diabetic medicine. 2000;17(7):524-7.

46. Fasanmade OA, Dagogo-Jack S. Diabetes Care in Nigeria. Ann Glob Health. 2015;81(6):8219.

47. Ogbera AO, Fasanmade $\mathrm{O}$, Ohwovoriole AE, Adediran $\mathrm{O}$. An assessment of the disease burden of foot ulcers in patients with diabetes mellitus attending a teaching hospital in Lagos, Nigeria. The international journal of lower extremity wounds. 2006;5(4):244-9.

48. Quaye EA, Amporful EO, Akweongo P, Aikins MK. Analysis of the Financial Cost of Diabetes Mellitus in Four Cocoa Clinics of Ghana. Value in health regional issues. 2015;7:49-53.

49. Suleiman IA, Festus JA. Cost of illness among diabetes mellitus patients in Niger Delta, Nigeria. J Pharm Health Serv Res. 2015;6(1):53-60.

50. Mutale W, Bosomprah S, Shankalala P, Mweemba O, Chilengi R, Kapambwe S, et al. Assessing capacity and readiness to manage NCDs in primary care setting: Gaps and opportunities based on adapted WHO PEN tool in Zambia. PloS one. 2018;13(8):e0200994-e.

51. Ministry of Health and Social Services, Primary Health Care Directorate, Namibia. National Multisectoral Strategic Plan For Prevention and Control of Non-Communicable Diseases (NCDs) in Namibia 2017/18 - 2021/22. 2017. Available at URL: https://www.iccp-

portal.org/system/files/plans/NAMIBIA\%20NATIONAL\%20MULTISECTORAL\%20STRATEGIC\%20PL AN\%20FOR\%20PREVENTION\%20AND\%20CONTROL\%20OF\%20NCDs.pdf.

52. Mukanu MM, Zulu JM, Mweemba C, Mutale W. Responding to non-communicable diseases in Zambia: a policy analysis. Health Research Policy and Systems. 2017;15(1):34.

53. Federal Ministry of Health, SIDCAIN, World Diabetes Foundation. Diabetes and NCDs in Nigeria - Perspectives, Challenges \& the Way Forward. 2017. Available at URL: http://sidcain.org/download/ABUJA\%20Proceedings\%20Reviewed\%20Nov\%202017.pdf. 54. NDOH. National Department of Health Republic of South Africa. Adherence Guidelines for HIV, TB and NCDs. Policy and service delivery guidelines to care, adherence to treatment and retention in care. February 2016. Available at URL: https://www.nacosa.org.za/wpcontent/uploads/2016/11/Integrated-Adherence-Guidelines-NDOH.pdf [ 55. KINGDOM OF ESWATINI - MINISTRY OF HEALTH. 2017 NATIONAL PREVENTION AND CONTROL OF NON COMMUNICABLE DISEASES (NCDs). 2017 Annual Program Report.

56. Igbojiaku OJ, Harbor OC, Ross A. Compliance with diabetes guidelines at a regional hospital in KwaZulu-Natal, South Africa. African Journal of Primary Health Care \& Family Medicine. 2013;5(1):447.

57. SEMDSA 2017 Guidelines for the Management of Type 2 diabetes mellitus. SEMDSA Type 2 Diabetes Guidelines Expert Committee. JEMDSA 2017; 22(1)(Supplement 1): S1-S196.

58. Awodele $\mathrm{O}$, Osuolale JA. Medication adherence in type 2 diabetes patients: study of patients in Alimosho General Hospital, Igando, Lagos, Nigeria. Afr Health Sci. 2015;15(2):513-22.

59. Botswana National Multisectoral Strategy for the Prevention and Control of NonCommunicable Diseases. 2017. Available at URL: https://www.iccpportal.org/system/files/plans/20171129\%20Botswana\%20multisec\%20NCDs\%20strategy\%20$\% 20$ final.pdf.

60. Khogali SS, Ali WA, Mohamed SY, Abdelrahim HE, Mirghani AA, Ali RH et al. Knowledge, attitude and practice of Sudanese individuals with type 2 diabetes about medication used in treatment of diabetes, hypertension and dyslipidaemia: a matter of debate or matter of concern? J Public Health Emerg. 2018;2:23.

61. Shannon GD, Haghparast-Bidgoli H, Chelagat W, Kibachio J, Skordis-Worrall J. Innovating to increase access to diabetes care in Kenya: an evaluation of Novo Nordisk's base of the pyramid project. Glob Health Action. 2019;12(1):1605704.

62. International Insulin Foundation - Fact Sheet on diabetes in sub-Saharan Africa. Available at URL: http://www.access2insulin.org/uploads/4/9/1/0/4910107/factsheet.pdf.

63. Djonou C, Tankeu AT, Dehayem MY, Tcheutchoua DN, Mbanya JC, Sobngwi E. Glycemic control and correlates in a group of sub Saharan type 1 diabetes adolescents. BMC research notes. 2019;12(1):50.

64. Balde N, Camara A, Sobngwi-Tambekou J, Balti EV, Tchatchoua A, Fezeu L, et al. Improving access to HbA1c in sub-Saharan Africa (IA3) cohort: cohort profile. The Pan African medical journal. 2017;27:275-. 
65. Park PH, Pastakia SD. Access to Hemoglobin A1c in Rural Africa: A Difficult Reality with Severe Consequences. Journal of diabetes research. 2018;2018:6093595.

66. Republic of Zambia. Ministry of Health. Zambia National Health Strategic Plan 2017-2021. Lusaka; 2017. Available at URL: https://www.moh.gov.zm/docs/ZambiaNHSP.pdf.

67. Tapela NM, Tshisimogo G, Shatera BP, Letsatsi V, Gaborone M, Madidimalo T, et al. Integrating noncommunicable disease services into primary health care, Botswana. Bulletin of the World Health Organization. 2019;97(2):142-53.

68. WHO Africa. The Team Type 1 Foundation and Abbott partner to donate glucose meters and nearly 12 million test strips to help people living with diabetes in Rwanda. 2020. Available at URL: https://www.afro.who.int/news/team-type-1-foundation-and-abbott-partner-donate-glucose-metersand-nearly-12-million-test.

69. Kenya Ministry of Health. Transforming Health: Accelerating attainment of Universal Health Coverage. The KENYA HEALTH SECTOR STRATEGIC AND INVESTMENT PLAN - KHSSP July 2012 -June 2017. Available at URL: http://e-cavi.com/wp-content/uploads/2014/11/kenya-healthsector-strategic-investiment-plan-2013-to-2017.pdf.

70. Rampamba EM, Meyer JC, Helberg EA, Godman B. Empowering Hypertensive Patients in South Africa to Improve Their Disease Management: A Pharmacist-Led Intervention. J Res Pharm Pract. 2019;8(4):208-13.

71. Atkilt HS, Turago MG, Tegegne BS. Clinical Characteristics of Diabetic Ketoacidosis in Children with Newly Diagnosed Type 1 Diabetes in Addis Ababa, Ethiopia: A Cross-Sectional Study. PloS one. 2017;12(1):e0169666-e.

72. Kitabchi AE, Umpierrez GE, Miles JM, Fisher JN. Hyperglycemic crises in adult patients with diabetes. Diabetes Care. 2009;32(7):1335-43.

73. Azevedo M, Alla S. Diabetes in sub-saharan Africa: kenya, mali, mozambique, Nigeria, South Africa and zambia. International journal of diabetes in developing countries. 2008;28(4):101-8.

74. Onyiriuka AN, Ifebi E. Ketoacidosis at diagnosis of type 1 diabetes in children and adolescents: frequency and clinical characteristics. Journal of diabetes and metabolic disorders. 2013;12(1):47.

75. Murunga AN, Owira PM. Diabetic ketoacidosis: an overlooked child killer in sub-Saharan Africa? Trop Med Int Health. 2013;18(11):1357-64.

76. Ndebele NFM, Naidoo M. The management of diabetic ketoacidosis at a rural regional hospital in KwaZulu-Natal. Afr J Prim Health Care Fam Med. 2018;10(1):e1-e6.

77. Majaliwa ES, Mohn A, Chiavaroli V, Ramaiya K, Swai AB, Chiarelli F. Management of diabetic ketoacidosis in children and adolescents in sub-Saharan Africa: a review. East Afr Med J. 2010;87(4):167-73.

78. lovane B, Cangelosi AM, Bonaccini I, Di Mauro D, Scarabello C, Panigari A, et al. Diabetic ketoacidosis at the onset of Type 1 diabetes in young children Is it time to launch a tailored campaign for DKA prevention in children <5 years? Acta bio-medica : Atenei Parmensis. 2018;89(1):67-71. 79. Van Zyl DG. Diagnosis and treatment of diabetic ketoacidosis. South African Family Practice. 2008;50(1):35-9.

80. Ngwiri T, Were F, Predieri B, Ngugi P, lughetti L. Glycemic Control in Kenyan Children and Adolescents with Type 1 Diabetes Mellitus. International journal of endocrinology. 2015;2015:761759. 81. Mukama LJ, Moran A, Nyindo M, Philemon R, Msuya L. Improved glycemic control and acute complications among children with type 1 diabetes mellitus in Moshi, Tanzania. Pediatric diabetes. 2013;14(3):211-6.

82. Emral R, Pathan F, Cortés CAY, El-Hefnawy MH, Goh S-Y, Gómez AM, et al. Self-reported hypoglycemia in insulin-treated patients with diabetes: Results from an international survey on 7289 patients from nine countries. Diabetes research and clinical practice. 2017;134:17-28.

83. Kalweit KL, Briers N, Olorunju S. The success of various management techniques used in South African children with type 1 diabetes mellitus. South African medical journal = Suid-Afrikaanse tydskrif vir geneeskunde. 2015;105(5):400-4.

84. Fulcher G, Singer J, Castañeda R, Fraige Filho F, Maffei L, Snyman J, et al. The psychosocial and financial impact of non-severe hypoglycemic events on people with diabetes: two international surveys. Journal of medical economics. 2014;17(10):751-61.

85. Muddu M, Mutebi E, Ssinabulya I, Kizito S, Mondo CK. Hypertension among newly diagnosed diabetic patients at Mulago National Referral Hospital in Uganda: a cross sectional study. Cardiovascular journal of Africa. 2018;29(4):218-24.

86. Ahmed SA, Badi S, Tahir H, Ahmed MH, Almobarak AO. Knowledge and practice of diabetic foot care in Sudan: A cross sectional survey. Diabetes \& metabolic syndrome. 2019;13(4):2431-5. 
87. Wagnew F, Eshetie S, Kibret GD, Zegeye A, Dessie G, Mulugeta H, et al. Diabetic nephropathy and hypertension in diabetes patients of sub-Saharan countries: a systematic review and meta-analysis. BMC research notes. 2018;11(1):565.

88. Hapunda G, Abubakar A, van de Vijver F, Pouwer F. Living with type 1 diabetes is challenging for Zambian adolescents: qualitative data on stress, coping with stress and quality of care and life. BMC endocrine disorders. 2015;15:20-

89. Rwegerera GM, Moshomo T, Gaenamong M, Oyewo TA, Gollakota S, Rivera YP, et al. Health-related quality of life and associated factors among patients with diabetes mellitus in Botswana. Alexandria Journal of Medicine. 2018;54(2):111-8.

90. da Mata AR, Alvares J, Diniz LM, da Silva MR, Alvernaz dos Santos BR, Guerra Junior AA, et al. Quality of life of patients with Diabetes Mellitus Types 1 and 2 from a referal health centre in Minas Gerais, Brazil. Expert review of clinical pharmacology. 2016;9(5):739-46.

91. Nieuwesteeg A, Pouwer F, van der Kamp R, van Bakel H, Aanstoot H-J, Hartman E. Quality of life of children with type 1 diabetes: a systematic review. Current diabetes reviews. 2012;8(6):43443.

92. Oluyombo R, Okunola OO, Olanrewaju TO, Soje MO, Obajolowo OO, Ayorinde MA. Challenges of hemodialysis in a new renal care center: call for sustainability and improved outcome. International journal of nephrology and renovascular disease. 2014;7:347-52.

93. Makhele L, Matlala M, Sibanda M, Martin AP, Godman B. A Cost Analysis of Haemodialysis and Peritoneal Dialysis for the Management of End-Stage Renal Failure At an Academic Hospital in Pretoria, South Africa. PharmacoEconomics - open. 2019.

94. Beran D, Hirsch IB, Yudkin JS. Why Are We Failing to Address the Issue of Access to Insulin? A National and Global Perspective. Diabetes Care. 2018;41(6):1125-31.

95. MANSFIELD J. TYPE 1 DIABETES IN GHANA: A GLOBAL COMMUNITY DISCUSSION. 2018. Available at URL: https://beyondtype1.org/type-1-diabetes-ghana/.

96. Pirie FJ, Jairam V, Paruk IM, Connolly C, Motala AA. High frequency of hypoglycaemia in patients with type 1 diabetes mellitus attending a tertiary diabetes clinic in Durban, South Africa. Diabetes research and clinical practice. 2019;155:107783.

97. Beran D, Ewan M, Laing R. Access to insulin - Current Challenges \& Constraints. October 2015. Available at URL: https://apps. who.int/medicinedocs/documents/s22269en/s22269en. pdf. 98. Ewen M, Joosse HJ, Beran D, Laing R. Insulin prices, availability and affordability in 13 lowincome and middle-income countries. BMJ global health. 2019;4(3):e001410.

99. Beran D, Ewen M, Laing R. Constraints and challenges in access to insulin: a global perspective. The lancet Diabetes \& endocrinology. 2016;4(3):275-85.

100. Beran D, Laing RO, Kaplan W, Knox R, Sharma A, Wirtz VJ, et al. A perspective on global access to insulin: a descriptive study of the market, trade flows and prices. Diabetic medicine. 2019;36(6):726-33.

101. Tiruneh GG, Abebe N, Dessie G. Self-reported hypoglycemia in adult diabetic patients in East Gojjam, Northwest Ethiopia: institution based cross-sectional study. BMC Endocr Disord. 2019;19(1):17.

102. Kahsay H, Fantahun B, Nedi T, Demoz GT. Evaluation of Hypoglycemia and Associated Factors among Patients with Type 1 Diabetes on Follow-Up Care at St. Paul's Hospital Millennium Medical College, Addis Ababa, Ethiopia. Journal of diabetes research. 2019;2019:9037374.

103. Kratzer J. Structural barriers to coping with type 1 diabetes mellitus in Ghana: experiences of diabetic youth and their families. Ghana medical journal. 2012;46(2 Suppl):39-45.

104. Tilnternational. Ghana. Available at URL: https://www.t1international.com/Ghana/.

105. World Health Organisation (WHO). Global action Plan for the prevention and control of noncommunicable diseases. 2013. Available at URL:

https://apps.who.int/iris/bitstream/handle/10665/94384/9789241506236_eng.pdf;jsessionid=7E6647E D415CFBF876A7CC201127FB76? sequence=1.

106. Kapwata T, Manda S. Geographic assessment of access to health care in patients with cardiovascular disease in South Africa. BMC health services research. 2018;18(1):197-.

107. Sandoz - A Novartis Division. Kenya is first country to launch 'Novartis Access', expanding affordable treatment options against chronic diseases. 2015. Available at URL:

https://www.sandoz.com/news/media-releases/kenya-first-country-launch-novartis-access-expandingaffordable-treatment.

108. Kabeza CB, Harst L, Schwarz PEH, Timpel P. Assessment of Rwandan diabetic patients' needs and expectations to develop their first diabetes self-management smartphone application (Kir'App). Therapeutic advances in endocrinology and metabolism. 2019;10:2042018819845318- 
109. Novo Nordisk. NOVO NORDISK EXPANDS PROGRAMME TO REACH 20,000 CHILDREN WITH DIABETES IN DEVELOPING COUNTRIES. 2016. Available at URL:

http://www.multivu.com/players/uk/7962351-novo-nordisk-programme-children-diabetes/.

110. Roche. Changing diabetes care for children in Africa. 2019. Available at URL:

https://www.roche.com/sustainability/access-to-healthcare/ath_diabetes.htm.

111. Pillay DK, Ross AJ, Campbell L. A review of hypoglycaemia in a South African family practice setting. African journal of primary health care \& family medicine. 2016;8(1):e1-e6.

112. Kaplan H, Amodb A, van Zyk FH, Reddy J, van Tondere A, Tsybale E. Incidence of hypoglycaemia in the South African population with diabetes: results from the IDMPS Wave 7 study. Journal of Endocrinology, Metabolism and Diabetes of South Africa 2019; 24(2):58-64.

113. WHO. World Health Organization Model List of Essential Medicines 2019. Available at URL: https://apps.who.int/iris/bitstream/handle/10665/325771/WHO-MVP-EMP-IAU-2019.06-

eng.pdf?ua=21st List 201.

114. Ogle GD, Kim H, Middlehurst AC, Silink M, Jenkins AJ. Financial costs for families of children with Type 1 diabetes in lower-income countries. Diabetic medicine. 2016;33(6):820-6.

115. Ogle GD, Middlehurst AC, Silink M. The IDF Life for a Child Program Index of diabetes care for children and youth. Pediatric diabetes. 2016;17(5):374-84.

116. Silver B, Ramaiya K, Andrew SB, Fredrick O, Bajaj S, Kalra S, et al. EADSG Guidelines:

Insulin Therapy in Diabetes. Diabetes therapy. 2018;9(2):449-92.

117. Zhang P, Zhang X, Brown J, Vistisen D, Sicree R, Shaw J, et al. Global healthcare expenditure on diabetes for 2010 and 2030. Diabetes research and clinical practice. 2010;87(3):293301.

118. Sherif S, Sumpio BE. Economic development and diabetes prevalence in MENA countries: Egypt and Saudi Arabia comparison. World journal of diabetes. 2015;6(2):304-11.

119. Pastakia SD, Nuche-Berenguer B, Pekny CR, Njuguna B, O'Hara EG, Cheng SY, et al. Retrospective assessment of the quality of diabetes care in a rural diabetes clinic in Western Kenya. BMC endocrine disorders. 2018;18(1):97-.

120. Matheka DM, Kilonzo JM, Munguti CM, Mwangi PW. Pattern, knowledge and practices of $\mathrm{HbA} 1 \mathrm{C}$ testing among diabetic patients in a Kenyan tertiary referral hospital. Globalization and health. 2013;9:55-.

121. Mbui JM, Oluka MN, Guantai EM, Sinei KA, Achieng L, Baker A, et al. Prescription patterns and adequacy of blood pressure control among adult hypertensive patients in Kenya; findings and implications. Expert review of clinical pharmacology. 2017;10(11):1263-71.

122. Nashilongo MM, Singu B, Kalemeera F, Mubita M, Naikaku E, Baker A, et al. Assessing Adherence to Antihypertensive Therapy in Primary Health Care in Namibia: Findings and Implications. Cardiovascular drugs and therapy. 2017;31(5-6):565-78.

123. Fadare J, Olamoyegun M, Gbadegesin BA. Medication adherence and direct treatment cost among diabetes patients attending a tertiary healthcare facility in Ogbomosho, Nigeria. Malawi Med J. 2015;27(2):65-70.

124. Mutyambizi C, Pavlova M, Chola L, Hongoro C, Groot W. Cost of diabetes mellitus in Africa: a systematic review of existing literature. Global Health. 2018;14(1):3.

125. Ogbera AO, Kuku SF. Insulin use, prescription patterns, regimens and costs.-a narrative from a developing country. Diabetology \& metabolic syndrome. 2012;4(1):50-.

126. Onyiriuka N, Ezomo OO, Onyiriuka RC. Cost of treating Insulin-requiring diabetes in children and adolescents. Journal of Institute of Medicine. 2012;34(1):2-8.

127. Yamey G, Fewer S, Beyeler N. Achieving a "Grand Convergence" in Global Health by 2035:

Rwanda Shows the Way Comment on "Improving the World's Health Through the Post-2015

Development Agenda: Perspectives From Rwanda". International journal of health policy and management. 2015;4(11):789-91.

128. Rwanda Diabetes Association. 2019. Available at URL: https://rwandadiabetes.com/.

129. Global Fund Grants in the Republic of Sudan - GF-OIG-19-010. Geneva, Switzerland. 2019.

Available from URL: https://www.theglobalfund.org/media/8433/oig_gf-oig-19-

010_report_en.pdf?u=637066540330000000.

130. Mohamed Ali, GK. 3,121 days in the driving seat of the National Medical Supplies Fund: What lessons to be shared? Book manuscript under proofreading for publication.

131. Elrayah H, Eltom M, Bedri A, Belal A, Rosling H, Ostenson C-G. Economic burden on families of childhood type 1 diabetes in urban Sudan. Diabetes research and clinical practice. 2005;70(2):15965.

132. Eliadarous H. Exploring the impact of diabetes in Sudan: Out-of-pocket expenditure and social consequences of diabetes on patients and their families. Stockholm, Sweden. 2017. Available 
at URL:

https://openarchive.ki.se/xmlui/bitstream/handle/10616/45956/Thesis_Hind_Eliadarous.pdf?sequence $=1$ \&isAllowed $=\mathrm{y}$.

133. Peck R, Mghamba J, Vanobberghen F, Kavishe B, Rugarabamu V, Smeeth L, et al.

Preparedness of Tanzanian health facilities for outpatient primary care of hypertension and diabetes: a cross-sectional survey. The Lancet Global health. 2014;2(5):e285-e92.

134. Kalungia CA, Mwale M, Sondashi IS, Mweetwa B, Yassa P, Kadimba G. Availability of Essential Antihypertensive and Antidiabetic Medicines in Public Health Facilities in Lusaka District, Zambia. Medical Journal of Zambia 2017; 44 (3): 140-8.

135. Kaiser AH, Hehman L, Forsberg BC, Simangolwa WM, Sundewall J. Availability, prices and affordability of essential medicines for treatment of diabetes and hypertension in private pharmacies in Zambia. PloS one. 2019;14(12):e0226169-e.

136. Jaam M, Ibrahim MIM, Kheir N, Awaisu A. Factors associated with medication adherence among patients with diabetes in the Middle East and North Africa region: A systematic mixed studies review. Diabetes research and clinical practice. 2017;129:1-15.

137. Majaliwa ES, Elusiyan BE, Adesiyun OO, Laigong P, Adeniran AK, Kandi CM, et al. Type 1 diabetes mellitus in the African population: epidemiology and management challenges. Acta biomedica : Atenei Parmensis. 2008;79(3):255-9.

138. Manne-Goehler J, Geldsetzer P, Agoudavi K, Andall-Brereton G, Aryal KK, Bicaba BW, et al. Health system performance for people with diabetes in 28 low- and middle-income countries: A crosssectional study of nationally representative surveys. PLoS Med. 2019;16(3):e1002751.

139. Owolabi MO, Yaria JO, Daivadanam M, Makanjuola AI, Parker G, Oldenburg B, et al. Gaps in Guidelines for the Management of Diabetes in Low- and Middle-Income Versus High-Income Countries-A Systematic Review. Diabetes care. 2018;41(5):1097-105.

140. Godman B, Haque M, McKimm J, Abu Bakar M, Sneddon J, Wale J, et al. Ongoing strategies to improve the management of upper respiratory tract infections and reduce inappropriate antibiotic use particularly among lower and middle-income countries: findings and implications for the future. Current medical research and opinion. 2020;36(2):301-27.

141. Godman B, Wettermark B, van Woerkom M, Fraeyman J, Alvarez-Madrazo S, Berg C, et al. Multiple policies to enhance prescribing efficiency for established medicines in Europe with a particular focus on demand-side measures: findings and future implications. Frontiers in pharmacology. 2014;5:106.

142. Godman B, Malmstrom RE, Diogene E, Jayathissa S, McTaggart S, Cars T, et al. Dabigatran - a continuing exemplar case history demonstrating the need for comprehensive models to optimize the utilization of new drugs. Frontiers in pharmacology. 2014;5:109.

143. Godman B, Malmstrom RE, Diogene E, Gray A, Jayathissa S, Timoney A, et al. Are new models needed to optimize the utilization of new medicines to sustain healthcare systems? Expert review of clinical pharmacology. 2015;8(1):77-94.

144. Godman B, Bucsics A, Vella Bonanno P, Oortwijn W, Rothe CC, Ferrario A, et al. Barriers for Access to New Medicines: Searching for the Balance Between Rising Costs and Limited Budgets.

Front Public Health. 2018;6:328.

145. Ermisch M, Bucsics A, Vella Bonanno P, Arickx F, Bybau A, Bochenek T, et al. Payers' Views of the Changes Arising through the Possible Adoption of Adaptive Pathways. Frontiers in pharmacology. 2016;7:305.

146. Godman B, Grobler C, Van-De-Lisle M, Wale J, Barbosa WB, Massele A, et al. Pharmacotherapeutic interventions for bipolar disorder type II: addressing multiple symptoms and approaches with a particular emphasis on strategies in lower and middle-income countries. Expert opinion on pharmacotherapy. 2019;20(18):2237-55.

147. Moorkens E, Vulto AG, Huys I, Dylst P, Godman B, Keuerleber S, et al. Policies for biosimilar uptake in Europe: An overview. PloS one. 2017;12(12):e0190147.

148. World Health Organisation. Definition and diagnosis of diabetes mellitus and intermediate hyperglycemia: report of a WHO/IDF consultation. Available atURL:

https://apps.who.int/iris/bitstream/handle/10665/43588/9241594934_eng.pdf;jsessionid=75A0C3B74F 6572D012AB00D9F8A23D4E? sequence=1.

149. WHO. Guidelines on second-and third-line medicines and type of insulin for the control of blood glucose levels in non-pregnant adults with diabetes mellitus. 2018. Available at URL: https://apps.who.int/iris/bitstream/handle/10665/272433/9789241550284-eng.pdf?ua=1.

150. Beran D, Ewen M, Lipska K, Hirsch IB, Yudkin JS. Availability and Affordability of Essential Medicines: Implications for Global Diabetes Treatment. Current diabetes reports. 2018;18(8):48. 
151. Ghana National Health Insurance Medicine list 2018. Avaiable at URL:

http://www.nhis.gov.gh/files/2018\%20NHIS\%20ML.pdf.

152. Government of the Kingdom of Swaziland Ministry of Health, the US President's Emergency Plan for AIDS Relief, USAID, and Strengthening Pharmaceutical Systems (SPS) Program. Standard Treatment Guidelines and Essential Medicines List of Common Medical Conditions in the Kingdom of Swaziland. 2012. Available at URL:

https://apps.who.int/medicinedocs/documents/s22119en/s22119en.pdf.

153. Kalk WJ, Raal J, Joffe BI. The prevalence and incidence of and risk factors for, microalbuminuria amongurban Africans with type 1 diabetes in South Africa: An inter-ethnic study. International Journal of Diabetes Mellitus. 2010; 2; 148-153.

154. Diabetes South Africa. The Tshwane Insulin Project. 2018. Available at URL:

https://www.diabetessa.org.za/the-tshwane-insulin-project/.

155. Ntuli C. Tuks sets up diabetes treatment programme. 2019. Available at URL:

https://www.iol.co.za/pretoria-news/tuks-sets-up-diabetes-treatment-programme-37175398.

156. Federal Ministry of Health, Sudan. National Essential Medicines List, 2014. Available from URL:

https://www.humanitarianresponse.info/sites/www.humanitarianresponse.info/files/documents/files/su dan_national_essential_medicines_list_.pdf.

157. Jonker D, Deacon E, van Rensburg E, Segal D. Illness perception of adolescents with wellcontrolled type 1 diabetes mellitus. Health Psychol Open. 2018;5(2):2055102918799968-.

158. Roth GA, Johnson C, Abajobir A, Abd-Allah F, Abera SF, Abyu G, et al. Global, Regional, and National Burden of Cardiovascular Diseases for 10 Causes, 1990 to 2015. Journal of the American College of Cardiology. 2017;70(1):1-25.

159. Joseph P, Leong D, McKee M, Anand SS, Schwalm JD, Teo K, et al. Reducing the Global Burden of Cardiovascular Disease, Part 1: The Epidemiology and Risk Factors. Circulation research. 2017;121(6):677-94.

160. Measuring progress and projecting attainment on the basis of past trends of the health-related Sustainable Development Goals in 188 countries: an analysis from the Global Burden of Disease Study 2016. Lancet. 2017;390(10100):1423-59.

161. United Nations. Sustainable Development Goal 3 - Ensure healthy lives and promote wellbeing for all at all ages. 2019. Available at URL: https://sustainabledevelopment.un.org/sdg3.

162. Morton S, Pencheon D, Squires N. Sustainable Development Goals (SDGs), and their implementation: A national global framework for health, development and equity needs a systems approach at every level. British medical bulletin. 2017;124(1):81-90.

163. Caires de Souza AL, de Assis Acurcio F, Guerra Junior AA, Rezende Macedo do Nascimento RC, Godman B, Diniz LM. Insulin glargine in a Brazilian state: should the government disinvest? An assessment based on a systematic review. Applied health economics and health policy.

2014;12(1):19-32.

164. de Souza AL, Acurcio Fde A, Guerra Junior AA, do Nascimento RC, Godman B, Diniz LM. Authors' reply to Dr. Malerbi: "Insulin glargine in a Brazilian state: should the government disinvest?". Applied health economics and health policy. 2014;12(5):561-3.

165. Almeida P, Silva TBC, de Assis Acurcio F, Guerra Junior AA, Araujo VE, Diniz LM, et al. Quality of Life of Patients with Type 1 Diabetes Mellitus Using Insulin Analog Glargine Compared with NPH Insulin: A Systematic Review and Policy Implications. The patient. 2018;11(4):377-89.

166. Marra LP, Araujo VE, Silva TB, Diniz LM, Guerra Junior AA, Acurcio FA, et al. Clinical Effectiveness and Safety of Analog Glargine in Type 1 Diabetes: A Systematic Review and MetaAnalysis. Diabetes therapy : research, treatment and education of diabetes and related disorders. 2016;7(2):241-58.

167. Institut für qualität und Wirtschaftlichkeit im Gesundheitswesen [Institute of Quality and Efficiency in Health Care]: Long-acting insulin analogues in the treatment of diabetes mellitus type 1. 2010. Available at URL: Http://www.iqwig.de/download/A05-01_Executive-Summary_Longacting_insulin_analogues_in_diabetes_mellitus_type_1.pdf 168. Holden SE, Poole CD, Morgan CL, Currie CJ. Evaluation of the incremental cost to the National Health Service of prescribing analogue insulin. BMJ open. 2011;1(2):e000258.

169. Horvath K, Jeitler K, Berghold A, Ebrahim SH, Gratzer TW, Plank J, et al. Long-acting insulin analogues versus NPH insulin (human isophane insulin) for type 2 diabetes mellitus. The Cochrane database of systematic reviews. 2007(2):Cd005613.

170. Singh SR, Ahmad F, Lal A, Yu C, Bai Z, Bennett H. Efficacy and safety of insulin analogues for the management of diabetes mellitus: a meta-analysis. CMAJ : Canadian Medical Association journal. 2009;180(4):385-97. 
171. Monami M, Marchionni N, Mannucci E. Long-acting insulin analogues vs. NPH human insulin in type 1 diabetes. A meta-analysis. Diabetes, obesity \& metabolism. 2009;11(4):372-8.

172. NICE. Type 1 diabetes in adults: diagnosis and management NICE guideline [NG17]. 2016. Available at URL: https://www.nice.org.uk/guidance/ng17.

173. Moodie P. More from PHARMAC on long-acting insulin analogues: insulin glargine now funded. The New Zealand medical journal. 2006;119(1236):U2040-U.

174. Meyer JC, Schellack N, Stokes J, Lancaster R, Zeeman H, Defty D, et al. Ongoing Initiatives to Improve the Quality and Efficiency of Medicine Use within the Public Healthcare System in South Africa; A Preliminary Study. Frontiers in pharmacology. 2017;8:751. 